Prepared in cooperation with the Missouri Department of Conservation

Determination of Polychlorinated Biphenyls, Selected Persistent Organochlorine Pesticides, and Polybrominated Flame Retardants in Fillets of Fishes from the 2006 Missouri Department of Conservation Monitoring Programs

Open-File Report 2008-1028 



\section{Determination of Polychlorinated Biphenyls, Selected Persistent Organochlorine Pesticides, and Polybrominated Flame Retardants in Fillets of Fishes from the 2006 Missouri Department of Conservation Monitoring Programs}

By Robert W. Gale', Thomas W. May', Carl E. Orazio', Michael J. McKee ${ }^{2}$

${ }^{1}$ U.S. Geological Survey

${ }^{2}$ Missouri Department of Conservation

Prepared in cooperation with the Missouri Department of Conservation

Open-File Report 2008-1028

U.S. Department of the Interior

U.S. Geological Survey 


\section{U.S. Department of the Interior DIRK KEMPTHORNE, Secretary}

\section{U.S. Geological Survey \\ Mark D. Myers, Director}

\section{U.S. Geological Survey, Reston, Virginia: 2008}

For product and ordering information:

World Wide Web: http://www.usgs.gov/pubprod

Telephone: 1-888-ASK-USGS

For more information on the USGS--the Federal source for science about the Earth, its natural and living resources, natural hazards, and the environment:

World Wide Web: http://www.usgs.gov

Telephone: 1-888-ASK-USGS

Any use of trade, product, or firm names is for descriptive purposes only and does not imply endorsement by the U.S. Government.

Although this report is in the public domain, permission must be secured from the individual copyright owners to reproduce any copyrighted materials contained within this report.

Suggested citation:

Gale, R.W., May, T.W., Orazio, C.E., and McKee, M.J., 2008, Determination of polychlorinated biphenyls, selected persistent organochlorine pesticides, and polybrominated flame retardants in fillets of fishes from the 2006 Missouri Department of Conservation Monitoring Programs: U.S. Geological Survey Open-File Report 2008-1028, 36 p. 


\section{Contents}

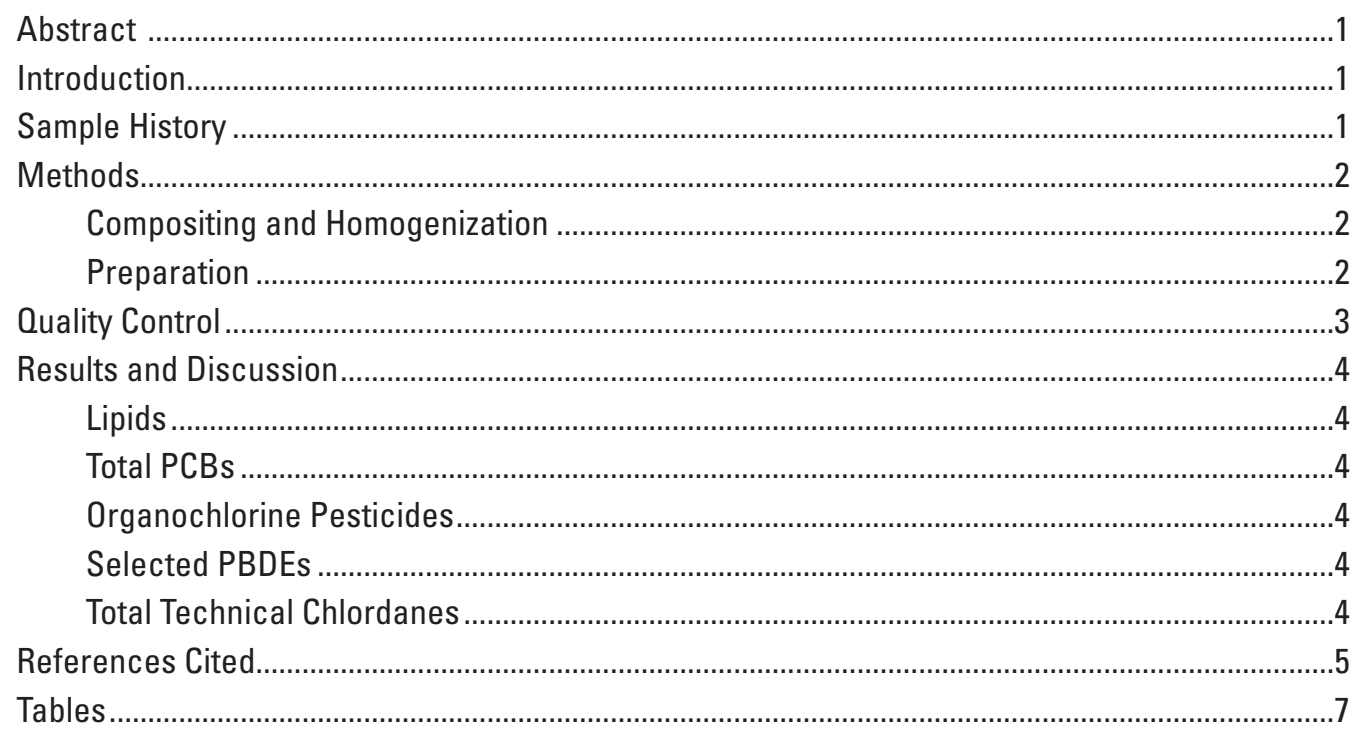

\section{Tables}

1. Sample description and percent lipid values in Missouri Department of Conservation 2006 General Contaminant Monitoring fish fillets.........................................8

2. Recoveries of Polychlorinated Biphenyl and Organochlorine Pesticide Procedural Internal Standards in Missouri Department of Conservation 2006 General Contaminant Monitoring fish fillets

3. Total polychlorinated biphenyl and estimated Aroclor ${ }^{\circledR}$ concentrations and Aroclor ${ }^{\circledR}$ percentages in Missouri Department of Conservation 2006 General Contaminant Monitoring fish fillets.

4. Organochlorine pesticide concentrations in Missouri Department of Conservation 2006 General Contaminant Monitoring fish fillets

5. Polybrominated diphenylethers concentrations and percentages in Missouri Department of Conservation 2006 General Contaminant Monitoring fish fillets.

6. Total chlordanes and summed target chlordane concentrations and percentages in Missouri Department of Conservation 2006 General Contaminant Monitoring fish fillets. 


\section{Conversion Factors}

\begin{tabular}{lcl}
\hline \multicolumn{1}{c}{ Multiply } & By & \multicolumn{1}{c}{ To obtain } \\
\hline milliliter $(\mathrm{mL})$ & Volume & \\
\hline & 0.03382 & ounce, fluid (fl. oz) \\
\hline gram (g) & Mass & \\
nanogram (ng) & 0.03527 & ounce, avoirdupois (oz) \\
nanogram (ng) & $1 \times 10^{-9}$ & gram \\
\hline & $3.527 \times 10^{-11}$ & ounce, avoirdupois $(\mathrm{oz})$ \\
\hline nanogram per gram $\left(\mathrm{ng} \cdot \mathrm{g}^{-1}\right)$ & Concentration & \\
nanogram per milliliter $\left(\mathrm{ng} \cdot \mathrm{mL}^{-1}\right)$ & $=$ & part per billion $\left(\mathrm{ppb} ; 10^{9}\right)$ \\
& $=$ & part per billion $\left(\mathrm{ppb} ; 10^{9}\right)$ \\
\hline
\end{tabular}

Temperature in degrees Celsius $\left({ }^{\circ} \mathrm{C}\right)$ may be converted to degrees Fahrenheit $\left({ }^{\circ} \mathrm{F}\right)$ as follows:

$$
{ }^{\circ} \mathrm{F}=\left(1.8 \times{ }^{\circ} \mathrm{C}\right)+32
$$

Concentrations of chemical constituents in solid materials (fish fillets) are given in nanogram per gram (ng/g). Concentrations of chemical constituents in liquid solutions (calibration standards) are given in nanogram per milliliter $(\mathrm{ng} / \mathrm{mL})$. 


\title{
Determination of Polychlorinated Biphenyls, Selected Persistent Organochlorine Pesticides, and Polybrominated Flame Retardants in Fillets of Fishes from the 2006 Missouri Department of Conservation Monitoring Programs
}

\author{
By Robert W. Gale', Thomas W. May', Carl E. Orazio', and Michael J. McKee ${ }^{2}$
}

\section{Abstract}

This report presents the results of a study to determine polychlorinated biphenyl, organochlorine pesticide, and polybrominated diphenyl ether flame retardant concentrations in selected fishes from lakes and streams across Missouri. Fillets were collected from each fish sample, and after homogenization, compositing, and preparation, analyte concentrations were determined with dual column capillary gas chromatography-electron-capture detection. Total concentrations of polychlorinated biphenyls in samples ranged from background levels of about 20 to 1,200 nanograms per gram. Chlordanes and DDT-related chemicals constituted the primary classes of pesticides present at elevated concentrations in most samples, and ranged from 5 to 340 nanograms per gram. Total concentrations of polybrominated diphenyl ethers in samples ranged from background levels of about 5 to about 410 nanograms per gram. Concentrations of total technical chlordane ranged from less than 5 to 260 nanograms per gram. Concentrations of polychlorinated biphenyls, chlordanes, DDT-related compounds, and polybrominated diphenyl ethers were all greatest in samples of blue catfish from Cape Girardeau and Weldon Spring.

\section{Introduction}

The Missouri Department of Conservation (MDC) began long-term state-wide fish monitoring programs in 1984 (Bataille, 2003, May and others 2007). The programs are designed to characterize contaminant concentrations at 20 to 30 lakes and streams throughout Missouri by annually collecting predator and bottom-feeding species samples. The

${ }^{1}$ U.S. Geological Survey.

${ }^{2}$ Missouri Department of Conservation. sites that are monitored each year vary based on data needs, budgets, and personnel resources. Emphasis is on human health and, therefore, incorporates fish fillets, composite samples, and sample replication at each site to assess any potential fish consumption risks. In 2006, 41 samples from 8 sites were selected for sampling as part of the MDC General Contaminant Monitoring Program. The following predator and bottom-feeding species were selected based on the need for organic contaminant information and the potentially greater risk for human consumption: largemouth bass (Micropterus salmoides); flathead catfish (Pylodictis Olivaris); blue catfish (Ictalurus Furcatus); and channel catfish (Ictalurus Punctatus). MDC has requested the collaborative assistance of the U.S. Geological Survey (USGS) for this monitoring program because of USGS's past experience with aquatic biota monitoring projects and expertise in the preparation and analysis of fish for trace-level organic contaminants.

\section{Sample History}

A shipment of 41 fish fillet composites was received by USGS on November 17, 2006. Upon receipt, the shipment was assigned USGS batch number 1316 and sample identification numbers 38400-38440 and all samples were logged into the data base and assigned data-base numbers. The identification numbers, MDC field identification, location descriptions, and sample percent lipids for each sample are listed in table 1, at the back of this report.

Fish were collected from eight Missouri sites: Cape Girardeau, Pool 22, Weldon Spring, Forest Lake, Phillips Lake, Hazel Creek Lake, Sumner, and Elam Bend. All samples had been stored since collection at the MDC's Resource Science Center in Columbia, Missouri and were delivered to USGS by MDC personnel. Requested analyses included total polychlorinated biphenyls (PCBs) and PCBs expressed as commercial Aroclor ${ }^{\circledR}$ mixtures historically reported in MDC 
monitoring programs, selected persistent organochlorine pesticides (OCPs), total technical chlordanes, and selected polybrominated diphenyl ethers (PBDEs).

\section{Methods}

\section{Compositing and Homogenization}

Most fish were divided into three five-fish fillet composites per site. Fish fillets were prepared by MDC personnel, frozen, and transported to the USGS in individually labeled bags. In some cases where fish were large, individual fillets were analyzed. Samples were stored frozen at -16 degrees Celsius $\left({ }^{\circ} \mathrm{C}\right)$ before composite homogenization. Fillets were ground and homogenized to prepare samples. The samples were stored in their original sample collection bags at $-16^{\circ} \mathrm{C}$ before analysis. Sample location information was obtained from the individually labeled bags.

\section{Preparation}

The procedure used to analyze the fish for PCBs, OCPs and PBDEs has been previously reported (Hinck and others, 2006). Briefly, 5-gram (g) portions of fish fillet composite samples were removed for analysis, dehydrated by addition of anhydrous $\mathrm{Na}_{2} \mathrm{SO}_{4}$, and spiked with procedural internal standards. Each sample was fortified with 40 nanograms (ng) of the following procedural internal standard constituents: 2,4,5-trichlorobiphenyl (PCB-029), 2,2',4,4',6,6'-hexachlorobiphenyl (PCB-155), 2,2',3,4,4',5,6,6'-octachlorobiphenyl (PCB-204), and deuterated $p, p^{\prime}-\mathrm{DDD}\left(p, p^{\prime}-\mathrm{DDD}-d_{8}\right.$ ) to monitor method recoveries.

As a trichlorobiphenyl, PCB-029 is representative of the more volatile $\mathrm{PCB}$ with one to three chlorine substitutions $\left(\mathrm{Cl}_{1}-\mathrm{Cl}_{3}\right)$; the PCB-155, a hexachlorobiphenyl, of mid-volatility-range $\mathrm{PCB}$ congeners with four to six chlorine substitutions $\left(\mathrm{Cl}_{4}-\mathrm{Cl}_{6}\right)$; and PCB-204, an octachlorobiphenyl, of PCBs with seven to ten chlorine substitutions $\left(\mathrm{Cl}_{7}-\mathrm{Cl}_{10}\right)$. The PCB procedural internal standards also were used to monitor recovery of the five less-polar pesticides collected in first silica gel fraction. The latter procedural internal standard, $p, p$ 'DDD- $d_{8}$, was used to monitor the recovery of more polar pesticides and PBDEs collected in the second silica gel fraction. The procedural internal standard compounds provide recovery information for each fraction of each sample and were used to monitor analyte concentrations.

The $\mathrm{Na}_{2} \mathrm{SO}_{4}$-dried fish tissue samples were column extracted with dichloromethane, concentrated to $10 \mathrm{~mL}$, and aliquants (2 percent of the extract) removed for lipid analysis determined as total non-volatile residues. Aliquants of the extracts (1.00-g equivalent) were removed for PCB analyses. These aliquants were treated by secondary reactive cleanup for removal of biogenic materials and analyzed by dual-column gas chromatography with electron-capture detection (GCECD).

Additional 1.00-g equivalent aliquants of the extracts were removed for OCP/PBDE analyses. Sequentially, lowperformance size exclusion chromatography (LP-SEC) and high-performance size exclusion chromatography (HP-SEC) were used to separate the analytes from residual higher molecular weight compounds in the lipophilic extracts. Next, the extracts were fractionated using layered octadecyl silica/ activated silica-gel open-column chromatography. The analytes were eluted with mobile phases containing increasing solvent polarities: fraction-one (F1), hexane eluent, collecting about 90 percent of the total PCBs (by mass) and six of the targeted OCPs; and fraction-two (F2), hexane/methyl t-butyl ether (55:45 volume/volume) eluent, collecting the residual 10 percent of the total PCBs (the less chlorinated congeners), the 23 remaining OCPs, and the PBDEs. The fractions were concentrated to 1.00 milliliter ( $\mathrm{mL}$ ) (1 g-equivalents per $\mathrm{mL}$ ).

An operational quality control (QC) system of checks was used to control and assess the measurement quality. This system of checks was managed by a quality assurance system that ensures that defined standards of quality are being met at stated levels of confidence. The accuracy and precision of environmental methods were assessed by utilizing appropriate checks for sample preparation and instrumental analysis. The appropriate QC sample types were selected based on the applicability to the objectives of this study, and were incorporated into the analysis plans, including procedural blanks, replicated fish fillet samples, fish tissue matrix blanks, analyte-fortified fish tissue matrix blanks, and positive control reference material (Saginaw Bay carp).

Instrumental internal standards (IIS) were added to each reactively cleaned-up fraction and final silica gel fraction, with the final volume of each fraction adjusted to $1.0 \mathrm{~mL}$. Individual congeners of PCBs, individual congeners of PBDEs, and organochlorine pesticides were measured in sample fractions by GC-ECD. Potential peaks for analytes were matched and identified on one or both gas chromatography (GC) capillary columns with individual standards. Up to nine levels of calibration for each analyte were used to quantify the targeted congeners. The calibration curves covered a concentration range of $0.01-0.03$ to 100 nanograms per milliliter $(\mathrm{ng} / \mathrm{mL})$.

Method reporting limits (MRLs) for total PCBs were set at the average total amounts measured in the procedural blanks run with each set based on the lowest calibration standard run in the calibration curve $(0.1 \mathrm{ng} / \mathrm{mL}$ per congener). The MRLs were set at $0.1 \mathrm{ng} / \mathrm{mL}$ for the OCPs and $0.2 \mathrm{ng} / \mathrm{mL}$ for PBDEs based on procedural background amounts and the analysis of low-level calibration standards. 


\section{Quality Control}

Recoveries of the procedural internal standards indicative of silica-gel fraction 1 OCP and PCB analytes (PCB-029, -155 and -204) were within quality-control guidelines of 50 to 125 percent, with the exception of sample USGS 38424-3 (MDC 2006-703-406-3) which incurred preparative losses and recoveries of 51 to 55 percent (table 2, at the back of this report). Recoveries of total PCBs from the fortified negative control matrix (whole bluegill) were 90 percent. The recovery of total PCBs from the positive control Saginaw Bay carp matrix ranged from 77 to 99 percent of the historical average (table 3, at the back of this report). The precision of replicate analyses ( $\mathrm{n}=3$ ) of samples USGS 38405 (MDC 2006-297-232-6) and USGS 38424 (MDC 2006-703-406-3) for total PCBs is presented in the table 3. Average concentrations of total PCBs were 20 and 98 nanograms per gram (ng/g) with relative standard deviations (RSD) of 25 and 11 percent, respectively. The greater RSD is a consequence of the lower concentration of total PCBs in USGS 38424, which is approaching background levels determined in procedural blank samples. The procedural blank analyses indicated normal background levels of total PCBs, ranging from 14 to 34 total ng per sample. The long term MRL for total PCBs at CERC is about $21 \mathrm{ng} / \mathrm{g}$. The correlation coefficients of the individual PCB congener calibration curves were greater than 0.95 , with nearly all correlation coefficients greater than 0.98 .

The recoveries of the procedural internal standard indicative of silica-gel fraction 2 OCP analytes $\left(p, p\right.$ '-DDD- $d_{8}$ ) were within quality-control guidelines (50 to 125 percent) with recoveries in most samples between 70 to 100 percent (table 2). Recoveries of OCPs from the fortified negative control matrix (whole bluegill) ranged from 49 to 145 percent, though for most analytes recoveries were more precise, averaging about 85 percent (table 4). The recovery of OCPs from the positive control Saginaw Bay carp matrix ranged from 76 to 129 percent of the historical average for those pesticides with concentrations significantly above the reporting limits (table 4 , at the back of this report). The precision of replicate analyses $(n=3)$ of samples USGS 38405 (MDC 2006-297-232-6) and USGS 38424 (MDC 2006-703-406-3) for OCPs are presented in the table 4. Only 12 OCPs were quantified at levels above the MRL $(0.1 \mathrm{ng} / \mathrm{g})$ in replicate USGS 38405, and 6 of these OCPs were less than $1 \mathrm{ng} / \mathrm{g}$ and had large RSDs (18 to 43 percent); the remaining OCPs concentrations ranged from 1 to $3 \mathrm{ng} / \mathrm{g}$ and had smaller RSDs (19 to 28 percent). The precision of methoxychlor $(4.1 \mathrm{ng} / \mathrm{g})$ was less than most other OCPs as a result of PBDE and PCB interferences. Only five OCPs were quantified at levels above the MRL in replicate USGS 38424, and none of these were greater than $1 \mathrm{ng} / \mathrm{g}$ in this composite fillet sample. The procedural blank analyses indicated negligible background levels of OCPs. The long term MRL for OCPs at CERC is less than $1 \mathrm{ng} / \mathrm{g}$. The correlation coefficients of the individual OCP calibration curves were greater than 0.95 , with nearly all correlation coefficients greater than 0.98 .
The procedural blank analyses indicated background levels of individual PBDEs ranging from less than 0.2 to $3 \mathrm{ng} / \mathrm{g}$, which should be considered when evaluating the lower PBDE concentration samples (table 5, at the back of this report). No additional quality-control measures specifically addressing PBDE recoveries were provided. The recovery of total PBDEs from the positive control Saginaw Bay carp matrix is undetermined because of the lack of historical PBDE information in this reference material. The precision of replicate analyses $(\mathrm{n}=3)$ of samples USGS 38405 (MDC 2006-297-232-6) and USGS 38424 (MDC 2006-703-406-3) for total PBDEs and selected congeners is presented in table 5. Average concentrations of total PBDEs were 15 and $4.9 \mathrm{ng} / \mathrm{g}$, with relative standard deviations of 14 and 20 percent, respectively. Again, the greater RSD is a consequence of the lower concentration of total PBDEs in USGS sample 38424, which is approaching background levels determined in procedural blank samples. The procedural blank analyses indicated normal background levels of total PBDEs, ranging from 4 to 8 total nanograms per sample. The correlation coefficients of the individual PBDE congener calibration curves were greater than 0.95 .

Recovery of technical chlordane from a fortified negative control matrix (whole bluegill) was 76 percent (table 6 , at the back of this report). The procedural blank analyses indicated background levels of individual chlordane components ranging from less than 0.1 to $1 \mathrm{ng} / \mathrm{g}$, total target chlordane ranging from 0.8 to $1.2 \mathrm{ng} / \mathrm{g}$, and total technical chlordane ranging from less than 5 to $24 \mathrm{ng} / \mathrm{g}$, the latter procedural blank values need to be considered when evaluating the lower technical chlordane concentration samples (table 6). The recovery of total technical chlordane from the positive control Saginaw Bay carp matrix is undetermined because of the lack of historical technical chlordane information in this reference material. However, it was determined that total targeted chlordane concentrations in the positive control samples were within 3 percent (average $74 \mathrm{ng} / \mathrm{g}$ ), and total technical chlordane concentrations were much more variable, ranging from 100 to $210 \mathrm{ng} / \mathrm{g}$. The large variation in total technical chlordane concentrations in the positive control material resulted from the complex nature of contaminants in the Saginaw Bay carp reference material and additional interferences from nonchlordane related components. The precision of replicate analyses ( $\mathrm{n}=3$ ) of samples USGS 38405 (MDC 2006-297-232-6) and USGS 38424 (MDC 2006-703-406-3) for total technical chlordane is presented in the table 6 . Concentrations of total target chlordanes were, of course, greater than those of total technical chlordanes in the OCP fortified negative control matrix (bluegill) samples. This is a direct result of significant concentrations of chlordane metabolites in the OCP fortification solution used. Average concentrations of total technical chlordane were less than 5 and $26 \mathrm{ng} / \mathrm{g}$, respectively. The correlation coefficients of the individual technical chlordane component calibration curves were greater than 0.95 . 


\section{Results and Discussion}

Forty-one fish fillet composite samples of predator and bottom-feeding fish were selected based on the need for organic contaminant information and the potentially greater risk for human consumption. Samples were collected from eight Missouri sites: Cape Girardeau, Pool 22, Weldon Spring, Forest Lake, Phillips Lake, Hazel Creek Lake, Sumner, and Elam Bend. Samples of individual or composited fish fillets are designated by USGS ID and by MDC field ID and are presented in table 1 . The composite samples were prepared and analyzed for PCBs, OCPs, and PBDEs by USGS, and the results are presented below.

\section{Lipids}

Lipids in the samples ranged from 0.30 to 18 percent and are reported in table 1 . Though largemouth bass and flathead catfish were lower in percent lipids than blue catfish or channel catfish, no trend in percent lipids in composited fillets was apparent between sites. Recoveries of procedural internal standards were within quality-control specifications, and generally ranged from 80 to 100 percent, which indicated complete extraction and recovery of the analytes (table 2). This indicated that extraction efficiencies for lipids (as total dichloromethane-extractable organophilic residues) were excellent.

\section{Total PCBs}

Polychlorinated biphenyl results for previous MDC monitoring programs were expressed as concentrations of Aroclors ${ }^{\circledR} 1242,1248,1254$, and 1260; therefore, the PCB congener results from this study were expressed as estimates of Aroclors ${ }^{\circledR}$ for compatibility (table 3 ). Response factors for three to four selected PCB congeners per Aroclor ${ }^{\circledR}$ were used to determine the fractional contribution of each congener to each Aroclor®: Aroclor® 1242-PCB-018, -019, -028, and -031; Aroclor ${ }^{\circledR} 1248-\mathrm{PCB}-066,-070$, and -074; Aroclor ${ }^{\circledR} 1254-\mathrm{PCB}-101,-110$, and -118; and Aroclor ${ }^{\circledR}$ 1260-PCB-153, -170, and -180.

Total concentrations of PCBs in samples ranged from background levels of about $20 \mathrm{ng} / \mathrm{g}$ to $1,200 \mathrm{ng} / \mathrm{g}$, the greatest value was present in a blue catfish composite from Weldon Spring, Missouri (table 3). Concentrations of PCBs were greatest in samples from blue catfish from Cape Girardeau and Weldon Spring. Expressed as Aroclors ${ }^{\circledR}$, PCBs primarily consisted of Aroclors ${ }^{\circledR} 1254$ and 1260, generally ranging from 20 to 80 percent of either Aroclor ${ }^{\circledR}$, though contributions of each varied among samples and areas. Smaller contributions to overall PCBs were estimated from Aroclor ${ }^{\circledR}$ 1248, ranging from 5 to 20 percent; negligible contributions, less than 10 percent, were estimated from Aroclor ${ }^{\circledR} 1242$.

\section{Organochlorine Pesticides}

Several OCPs were detected in most samples and were present at 10- to 20-fold greater levels in about one-half of the samples and are reported in table 4. Chlordanes (cis/trans-nonachlor, cis/trans-chlordane, oxychlordane, heptachlor epoxide, and methoxychlor) and DDT-related chemicals ( $p, p^{\prime}$-DDE, $p, p^{\prime}-\mathrm{DDD}, p, p^{\prime}$-DDT, and $o, p^{\prime}$-DDT) constituted the primary classes of pesticides detected at elevated concentrations in most samples, and ranged from 5 to $340 \mathrm{ng} / \mathrm{g}$, the greatest $p, p$ '-DDE value was detected for a blue catfish composite from Weldon Spring. Other OCP concentrations in samples generally were low. Hexachlorocyclohexanes ( $\alpha$-BHC, $\beta$-BHC, $\gamma$-BHC 'Lindane', $\delta$-BHC), heptachlor, endosulfans (I, II, sulfate), endrin, aldrin, pentachlorobenzene, hexachlorobenzene, dacthal, heptachlor, and $o, p^{\prime}$-DDD and $o, p^{\prime}$-DDE were not present in any sample at concentrations greater than $5 \mathrm{ng} / \mathrm{g}$.

\section{Selected PBDEs}

Total concentrations of PBDEs in samples ranged from background levels of about 5 to about $410 \mathrm{ng} / \mathrm{g}$, the greatest value present in a blue catfish composite sample from Weldon Spring, and are reported in table 5. Concentrations of total PBDEs correlated well with concentrations of total PCBs in the fish fillet composites $\left(\mathrm{r}^{2}\right.$ 0.93). Concentrations of PBDEs, like those of total PCBs, were greatest in samples from blue catfish from Cape Girardeau and Weldon Spring. Of the target PBDE congeners, PBDE-047 contributed from 30 to 70 percent and PBDE-099 contributed from 10 to 50 percent of the total PBDE, respectively; together, these two congeners accounted for 48 to 88 percent of the total PBDEs in all samples. The next most significant contribution was from PBDE-085 (less than 1 to about 33 percent). Smaller contributions to overall PBDEs were made by the remaining targeted congeners, with no congener contributing greater than about 15 percent to any sample.

\section{Total Technical Chlordanes}

The eight targeted components of chlordane or its metabolites (heptachlor, heptachlor epoxide, oxychlordane, cis/trans-chlordane, cis/trans-nonachlor, and methoxychlor) historically have been selected for monitoring based on their persistence in fish (Hinck and others, 2006). In addition to these 8 targeted chlordane components, the fish fillet composite samples were analyzed for the 31 primary components of technical chlordane to determine the extent of any additional persistent, bioaccumulative technical chlordane components versus metabolites. Total technical chlordane analysis included heptachlor, cis/trans-chlordane, and cis/trans-nonachlor, but excluded the metabolites heptachlor epoxide, oxychlordane, and methoxychlor. These technical chlordane components were selected based on their mass contribution to technical chlordane, their fractionation throughout the preparation 
procedure, and their resolution from chromatographically interfering co-contaminants. Concentrations of total targeted chlordane and total technical chlordane ranged from 1 to 190 $\mathrm{ng} / \mathrm{g}$ and from less than 5 to $260 \mathrm{ng} / \mathrm{g}$, respectively; the greatest values for each were detected in a blue catfish composite sample from Weldon Spring. Concentrations of total technical chlordane correlated well with concentrations of total targeted chlordanes $\left(\mathrm{r}^{2} 0.99\right)$ and generally were about 38 percent greater from contributions of the 25 additional chlordane components, less the chlordane metabolites. Differences between technical chlordane and targeted chlordane concentrations were most apparent at low concentrations, where chlordane metabolites could increase the concentrations of target chlordanes relative to total technical chlordanes. Again, concentrations of total targeted chlordane and technical chlordane correlated well with concentrations of total PCBs in the fish fillet composites ( $\mathrm{r}^{2}$ 0.92-0.93). Concentrations of chlordanes, like those of total PBDEs and total PCBs, were greatest in samples from blue catfish from Cape Girardeau and Weldon Spring.

\section{References Cited}

Bataille, K.J. 2003. Contaminant concentrations in Missouri Fish-2001: Missouri Department of Conservation Internal Publication.

May, T.W., Walther, M.J., Brumbaugh, W.G., 2007, Concentrations of elements in hellbender blood and fish fillets from the 2006 Missouri Department of Conservation Monitoring Programs: U.S. Geological Survey Open-File Report 2007-1299, 18 p.

Hinck, J.E., Blazer, V.S., Denslow, N.D., Gross, T.S., Echols, K.R., Davis, A.P., May, T.W., Orazio, C.E., Coyle, J.J., and Tillitt, D.E., 2006, Biomonitoring of Environmental Status arid Trends (BEST) Program: environmental contaminants, health indicators, and reproductive biomarkers in fish from the Colorado River Basin: U.S. Geological Survey Scientific Investigations Report 2006-5163, 119 p. 

Tables 
Table 1. Sample description and percent lipid values in Missouri Department of Conservation 2006 General Contaminant Monitoring fish fillets.

[USGS, U.S. Geological Survey; ID, identification; MDC, Missouri Department of Conservation; Average, average of replicate analyses; SD, standard deviation; RSD, percent relative standard deviation; <, less than; --, no data]

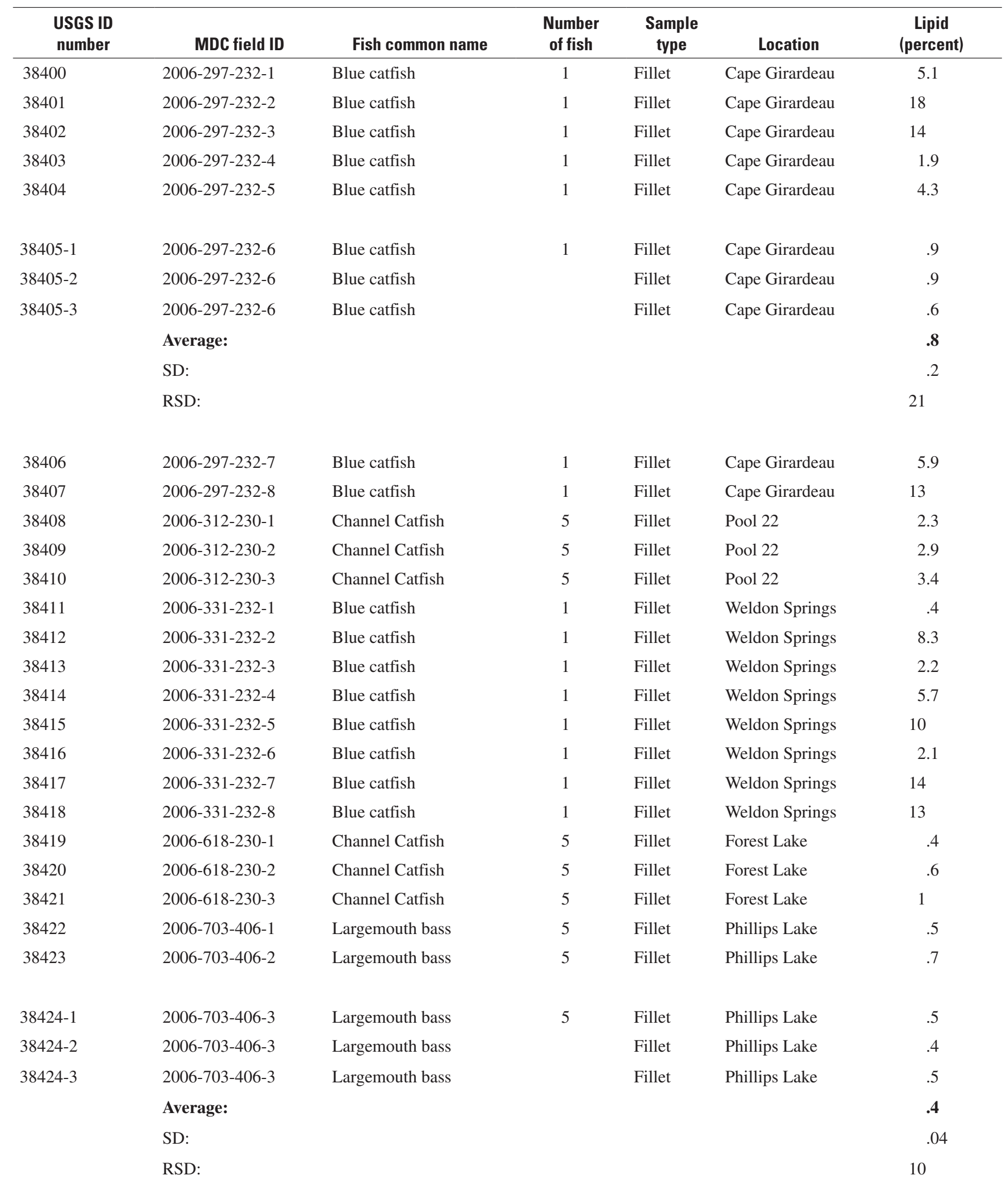


Table 1. Sample description and percent lipid values in Missouri Department of Conservation 2006 General Contaminant Monitoring fish fillets.-Continued

[USGS, U.S. Geological Survey; ID, identification; MDC, Missouri Department of Conservation; Average, average of replicate analyses; SD, standard deviation; RSD, percent relative standard deviation; <, less than; --, no data]

\begin{tabular}{|c|c|c|c|c|c|c|}
\hline $\begin{array}{l}\text { USGS ID } \\
\text { number }\end{array}$ & MDC field ID & Fish common name & $\begin{array}{l}\text { Number } \\
\text { of fish }\end{array}$ & $\begin{array}{c}\text { Sample } \\
\text { type }\end{array}$ & Location & $\begin{array}{c}\text { Lipid } \\
\text { (percent) }\end{array}$ \\
\hline 38425 & 2006-704-406-1 & Largemouth bass & 5 & Fillet & Hazel Creek Lake & .8 \\
\hline 38426 & 2006-704-406-2 & Largemouth bass & 5 & Fillet & Hazel Creek Lake & 1.1 \\
\hline 38427 & 2006-704-406-3 & Largemouth bass & 5 & Fillet & Hazel Creek Lake & .6 \\
\hline 38428 & $2006-705-245-1$ & Flathead catfish & 1 & Fillet & Sumner & 1.4 \\
\hline 38429 & $2006-705-245-2$ & Flathead catfish & 1 & Fillet & Sumner & .6 \\
\hline 38430 & $2006-705-245-3$ & Flathead catfish & 1 & Fillet & Sumner & 1.6 \\
\hline 38431 & $2006-705-245-4$ & Flathead catfish & 1 & Fillet & Sumner & .5 \\
\hline 38432 & $2006-705-245-5$ & Flathead catfish & 1 & Fillet & Sumner & .3 \\
\hline 38433 & $2006-705-245-6$ & Flathead catfish & 1 & Fillet & Sumner & .8 \\
\hline 38434 & $2006-705-245-7$ & Flathead catfish & 1 & Fillet & Sumner & 1.2 \\
\hline 38435 & $2006-705-245-8$ & Flathead catfish & 1 & Fillet & Sumner & 1.7 \\
\hline 38436 & $2006-705-245-9$ & Flathead catfish & 1 & Fillet & Sumner & 1 \\
\hline 38437 & $2006-705-245-10$ & Flathead catfish & 1 & Fillet & Sumner & .7 \\
\hline 38438 & 2006-705-245-11 & Flathead catfish & 1 & Fillet & Sumner & .8 \\
\hline 38439 & $2006-705-245-12$ & Flathead catfish & 1 & Fillet & Sumner & 1.7 \\
\hline 38440 & 2006-706-245-1 & Flathead catfish & 1 & Fillet & Elam bend & .5 \\
\hline PB-122106 & Procedural Blank & -- & -- & -- & & $<0.1$ \\
\hline \multirow[t]{2}{*}{ PB-010207 } & Procedural Blank & -- & -- & -- & & $<0.1$ \\
\hline & Average: & & & & & $<0.1$ \\
\hline MB-010107 & Matrix Blank & Control Bluegill 654C & & Whole & & 3.7 \\
\hline \multirow[t]{2}{*}{ MB-010307 } & Matrix Blank & Control Bluegill 654C & & Whole & & 3.7 \\
\hline & Average: & & & & & 3.7 \\
\hline MS-OC-010107 & Matrix Spike - OCs & Control Bluegill 654C & & Whole & & 3.6 \\
\hline \multirow[t]{2}{*}{ MS-OC-010307 } & Matrix Spike - OCs & Control Bluegill 654C & & Whole & & 4.1 \\
\hline & Average: & & & & & 3.9 \\
\hline MS-PCB-010107 & Matrix Spike - PCBs & Control Bluegill 654C & & Whole & & 3.7 \\
\hline \multirow[t]{2}{*}{ MS-PCB-010307 } & Matrix Spike - PCBs & Control Bluegill 654C & & Whole & & 3.4 \\
\hline & Average: & & & & & 3.6 \\
\hline PC-122106 & Positive Control & Saginaw Carp 6806-148 & & Whole & & 16 \\
\hline \multirow[t]{2}{*}{ PC-010207 } & Positive Control & Saginaw Carp 6806-148 & & Whole & & 13 \\
\hline & Average: & & & & & 14 \\
\hline
\end{tabular}


Table 2. Recoveries of Polychlorinated Biphenyl and Organochlorine Pesticide Procedural Internal Standards in Missouri Department of Conservation 2006 General Contaminant Monitoring fish fillets.

[USGS, U.S. Geological Survey; ID, identification; MDC, Missouri Department of Conservation; PCB, Polychlorinated Biphenyl; $p, p^{\prime}$-DDD- $d_{8}$, Octadeuterated $p, p^{\prime}$-DDD]

\begin{tabular}{|c|c|c|c|c|c|}
\hline USGS ID number & $\begin{array}{c}\text { MDC } \\
\text { field ID }\end{array}$ & $\begin{array}{l}\text { PCB-029 } \\
\text { (percent) }\end{array}$ & $\begin{array}{l}\text { PCB-155 } \\
\text { (percent) }\end{array}$ & $\begin{array}{c}\text { PCB-204 } \\
\text { (percent) }\end{array}$ & $\begin{array}{c}p, p^{\prime}-\mathrm{DDD}-d_{8} \\
\text { (percent) }\end{array}$ \\
\hline 38400 & 2006-297-232-1 & 86 & 92 & 93 & 102 \\
\hline 38402 & $2006-297-232-3$ & 89 & 93 & 93 & 106 \\
\hline 38403 & $2006-297-232-4$ & 87 & 88 & 91 & 94 \\
\hline $38405-1$ & $2006-297-232-6$ & 83 & 90 & 94 & 101 \\
\hline $38405-2$ & $2006-297-232-6$ & 87 & 91 & 95 & 98 \\
\hline $38405-3$ & $2006-297-232-6$ & 80 & 89 & 95 & 95 \\
\hline 38408 & 2006-312-230-1 & 76 & 86 & 92 & 87 \\
\hline 38409 & $2006-312-230-2$ & 83 & 87 & 92 & 95 \\
\hline 38410 & $2006-312-230-3$ & 89 & 86 & 94 & 88 \\
\hline 38411 & 2006-331-232-1 & 89 & 88 & 95 & 100 \\
\hline 38412 & $2006-331-232-2$ & 89 & 90 & 92 & 88 \\
\hline 38413 & $2006-331-232-3$ & 87 & 86 & 89 & 101 \\
\hline 38414 & $2006-331-232-4$ & 91 & 87 & 93 & 98 \\
\hline 38415 & $2006-331-232-5$ & 93 & 93 & 92 & 105 \\
\hline 38422 & 2006-703-406-1 & 89 & 85 & 89 & 75 \\
\hline 38423 & $2006-703-406-2$ & 84 & 86 & 88 & 72 \\
\hline $38424-1$ & $2006-703-406-3$ & 84 & 89 & 91 & 79 \\
\hline $38424-2$ & $2006-703-406-3$ & 90 & 90 & 93 & 78 \\
\hline $38424-3$ & $2006-703-406-3$ & 55 & 49 & 51 & 76 \\
\hline 38425 & 2006-704-406-1 & 90 & 85 & 86 & 74 \\
\hline 38426 & $2006-704-406-2$ & 91 & 87 & 90 & 76 \\
\hline 38427 & $2006-704-406-3$ & 84 & 86 & 87 & 70 \\
\hline 38428 & $2006-705-245-1$ & 93 & 90 & 92 & 87 \\
\hline 38429 & $2006-705-245-2$ & 85 & 89 & 91 & 77 \\
\hline
\end{tabular}


Table 2. Recoveries of Polychlorinated Biphenyl and Organochlorine Pesticide Procedural Internal Standards in Missouri Department of Conservation 2006 General Contaminant Monitoring fish fillets.-Continued

[USGS, U.S. Geological Survey; ID, identification; MDC, Missouri Department of Conservation; PCB, Polychlorinated Biphenyl; $p, p^{\prime}$-DDD- $d_{8}$, Octadeuterated $p, p^{\prime}$-DDD]

\begin{tabular}{|c|c|c|c|c|c|}
\hline USGS ID number & $\begin{array}{c}\text { MDC } \\
\text { field ID }\end{array}$ & $\begin{array}{c}\text { PCB-029 } \\
\text { (percent) }\end{array}$ & $\begin{array}{l}\text { PCB-155 } \\
\text { (percent) }\end{array}$ & $\begin{array}{c}\text { PCB-204 } \\
\text { (percent) }\end{array}$ & $\begin{array}{c}p, p^{\prime}-\mathrm{DDD}-d_{8} \\
\text { (percent) }\end{array}$ \\
\hline 38430 & 2006-705-245-3 & 86 & 89 & 88 & 74 \\
\hline 38431 & $2006-705-245-4$ & 88 & 91 & 90 & 85 \\
\hline 38432 & $2006-705-245-5$ & 91 & 89 & 90 & 73 \\
\hline 38433 & 2006-705-245-6 & 83 & 85 & 85 & 69 \\
\hline 38434 & 2006-705-245-7 & 85 & 88 & 89 & 72 \\
\hline 38435 & $2006-705-245-8$ & 81 & 87 & 88 & 72 \\
\hline 38436 & 2006-705-245-9 & 88 & 88 & 87 & 74 \\
\hline 38437 & 2006-705-245-10 & 94 & 91 & 89 & 73 \\
\hline 38438 & 2006-705-245-11 & 94 & 90 & 89 & 74 \\
\hline 38439 & $2006-705-245-12$ & 96 & 95 & 95 & 78 \\
\hline 38440 & 2006-706-245-1 & 93 & 92 & 92 & 70 \\
\hline PB-122106 & Procedural Blank & 84 & 85 & 89 & 93 \\
\hline PB-010207 & Procedural Blank & 59 & 85 & 90 & 73 \\
\hline MB-010107 & Matrix Blank & 74 & 84 & 92 & 85 \\
\hline MB-010307 & Matrix Blank & 83 & 90 & 90 & 71 \\
\hline MS-OC-010107 & Matrix Spike - OCs & 85 & 84 & 88 & 92 \\
\hline MS-OC-010307 & Matrix Spike - OCs & 86 & 92 & 92 & 85 \\
\hline MS-PCB-010107 & Matrix Spike - PCBs & 96 & 87 & 97 & 101 \\
\hline MS-PCB-010307 & Matrix Spike - PCBs & 83 & 126 & 84 & 68 \\
\hline PC-122106 & Positive Control & 91 & 76 & 103 & 102 \\
\hline PC-010207 & Positive Control & 88 & 79 & 98 & 100 \\
\hline
\end{tabular}




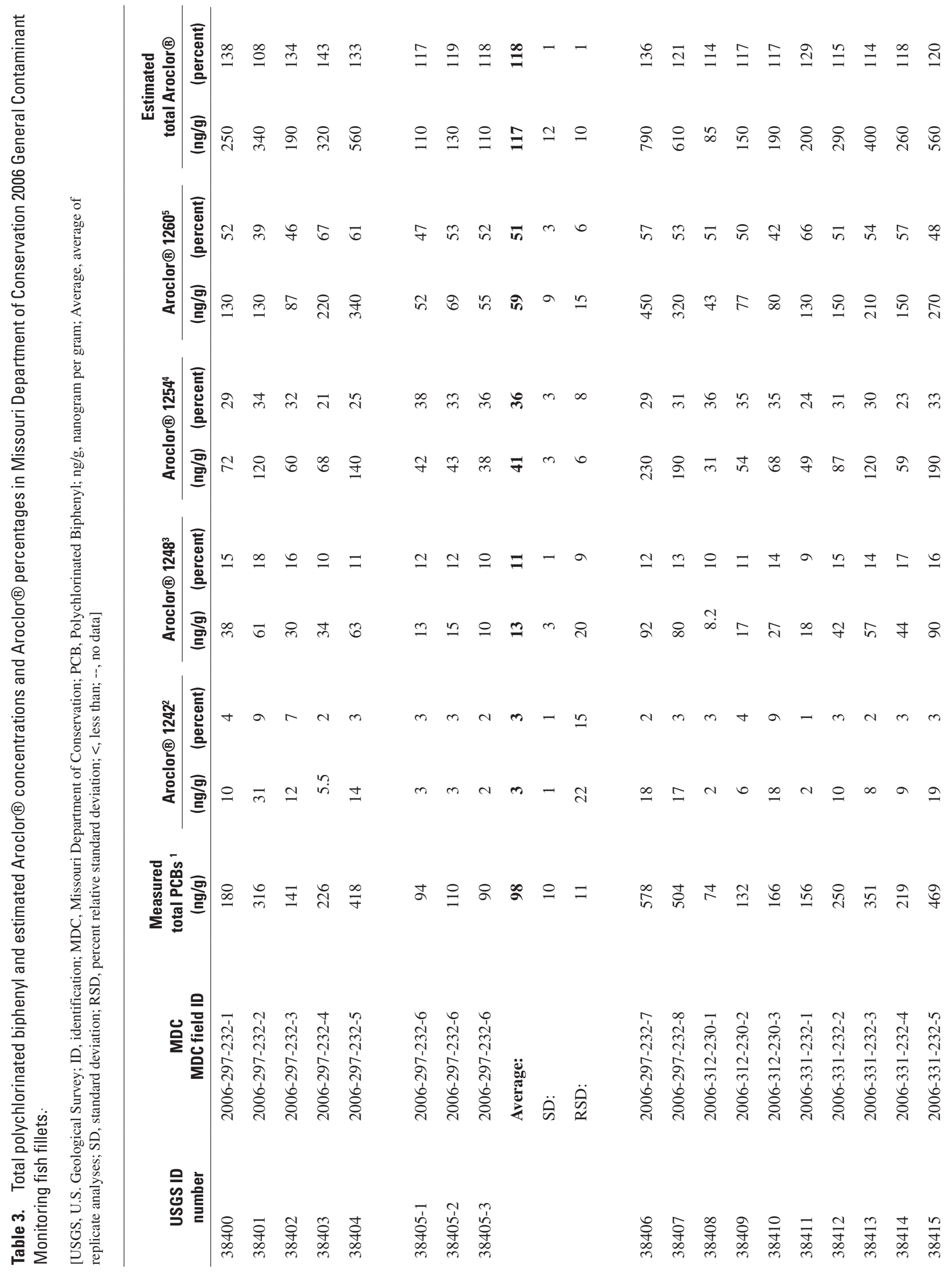




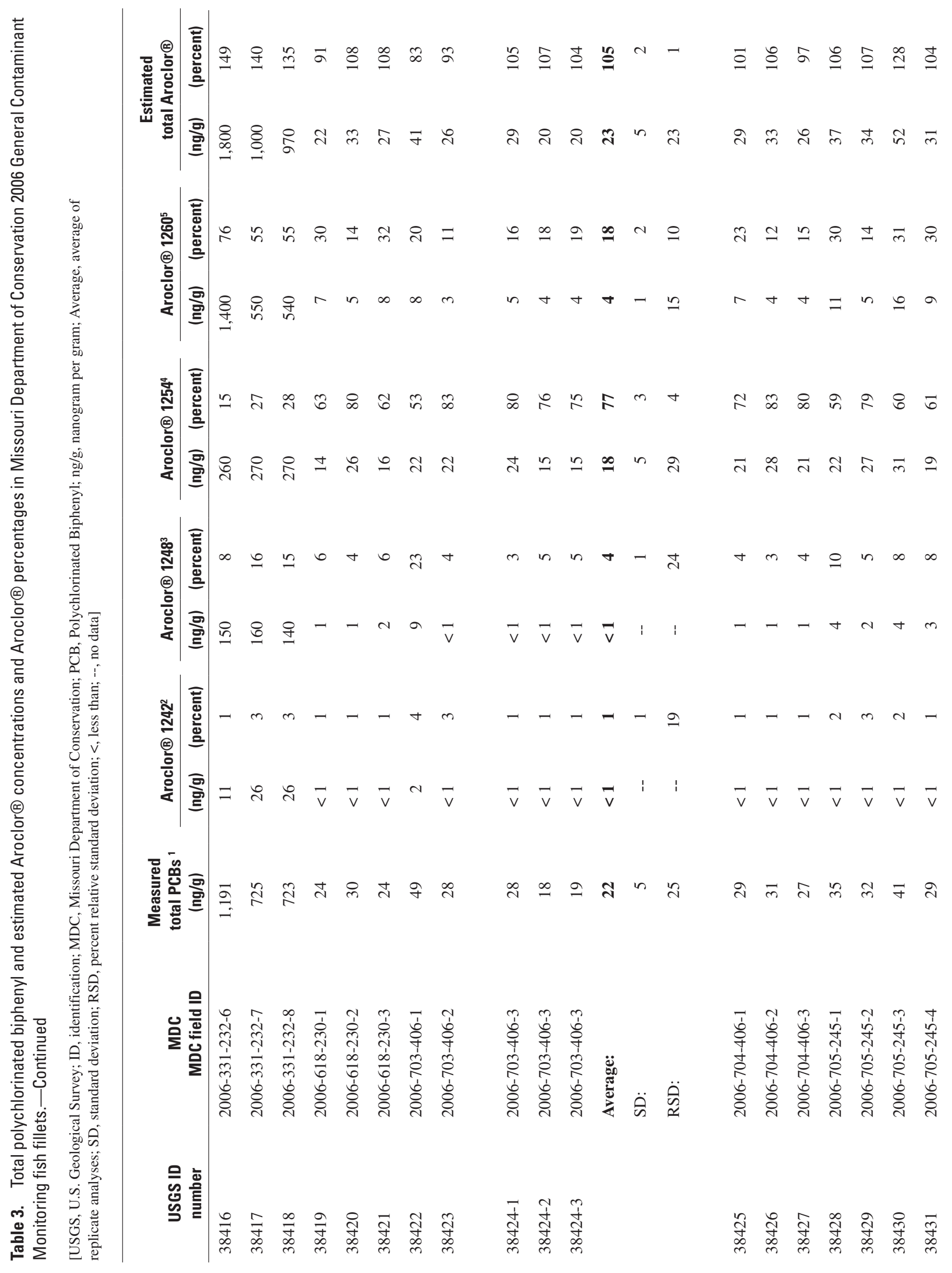




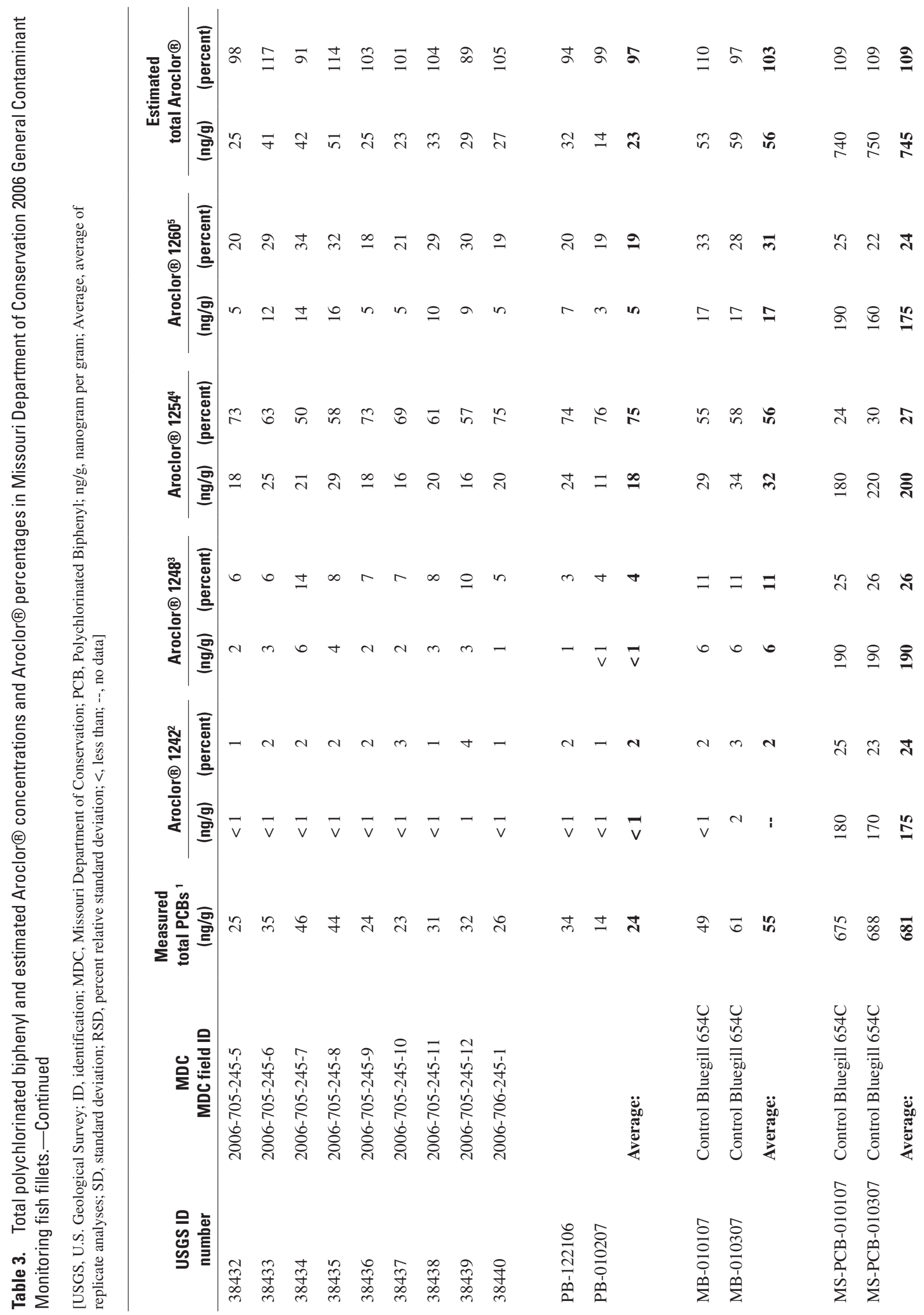




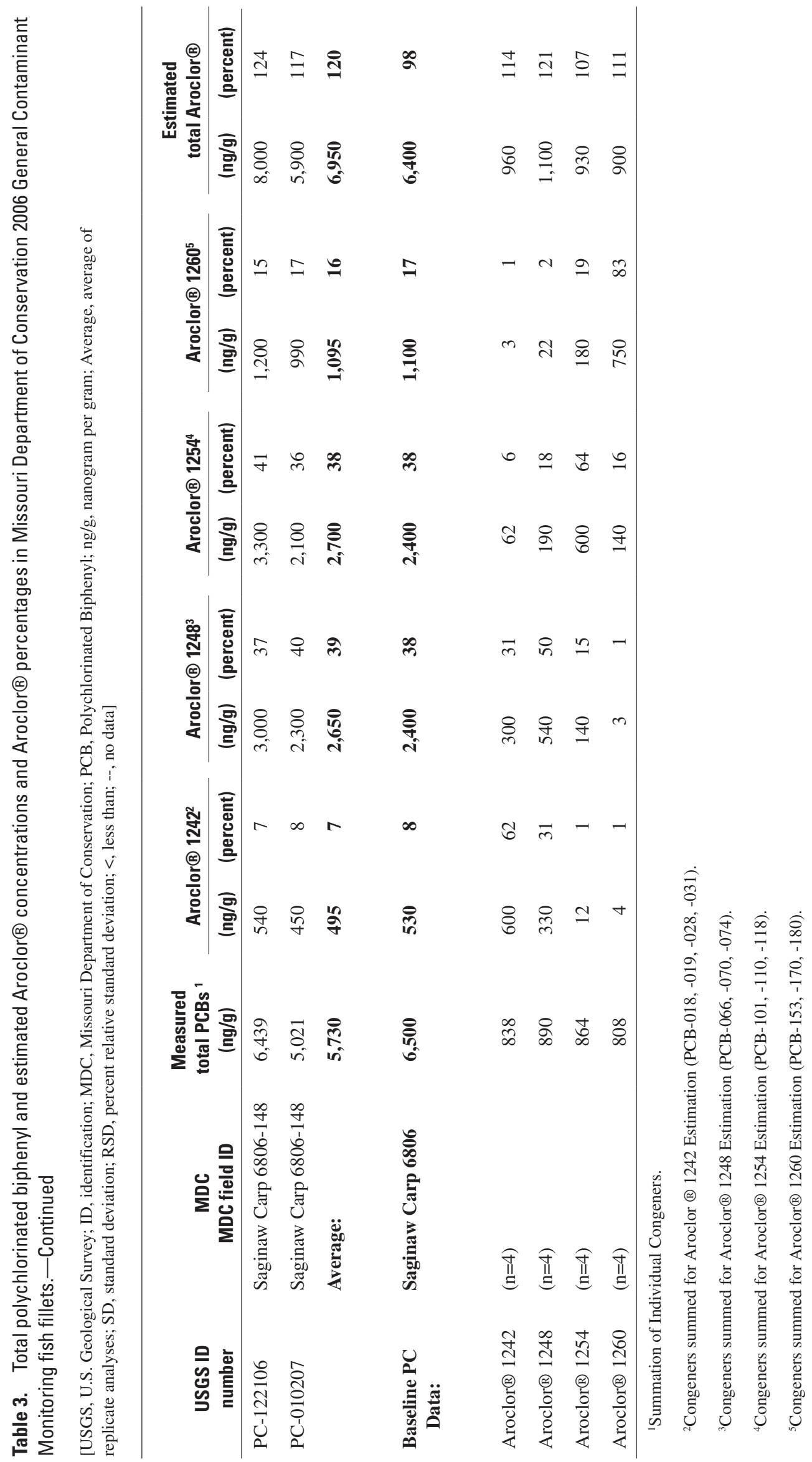




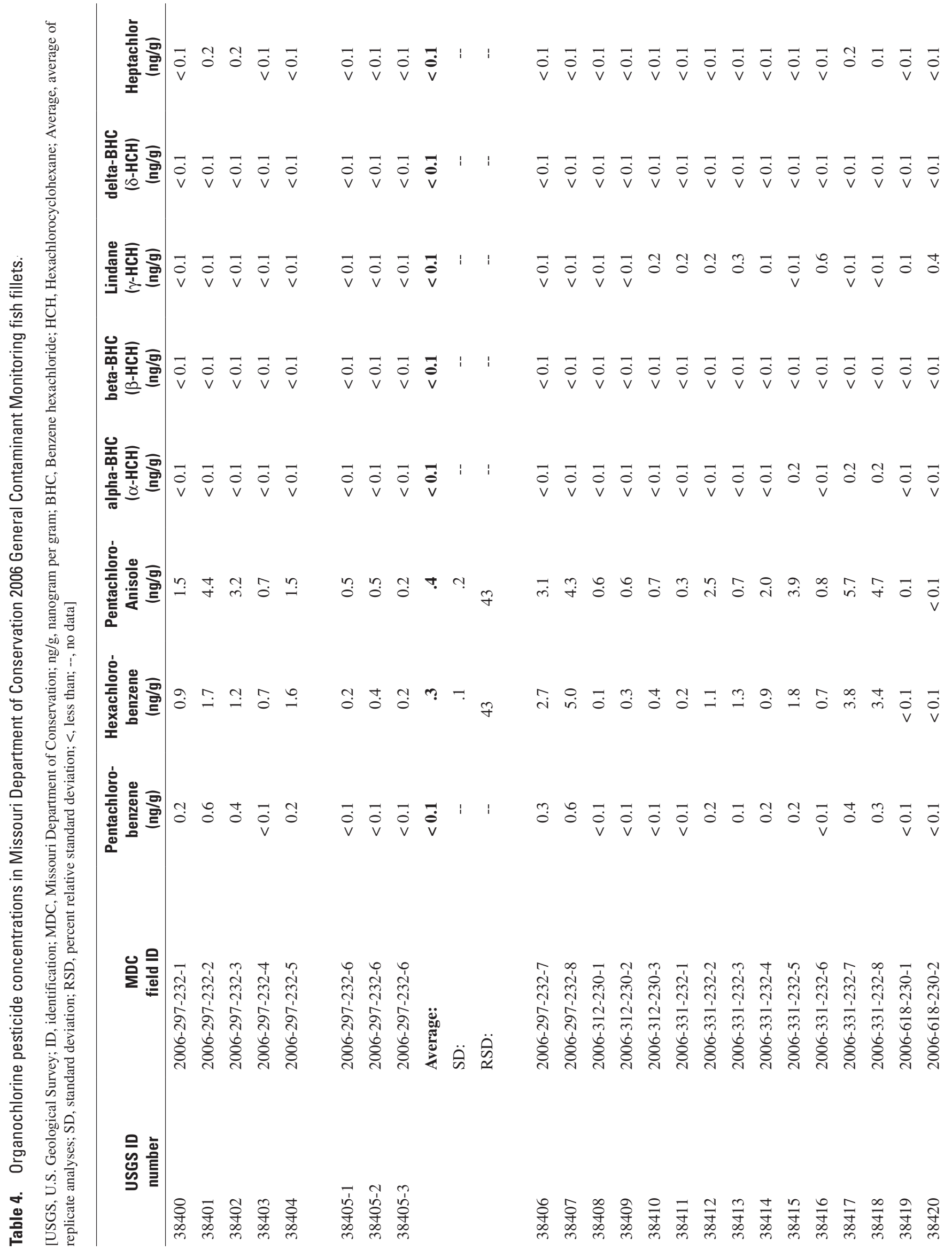




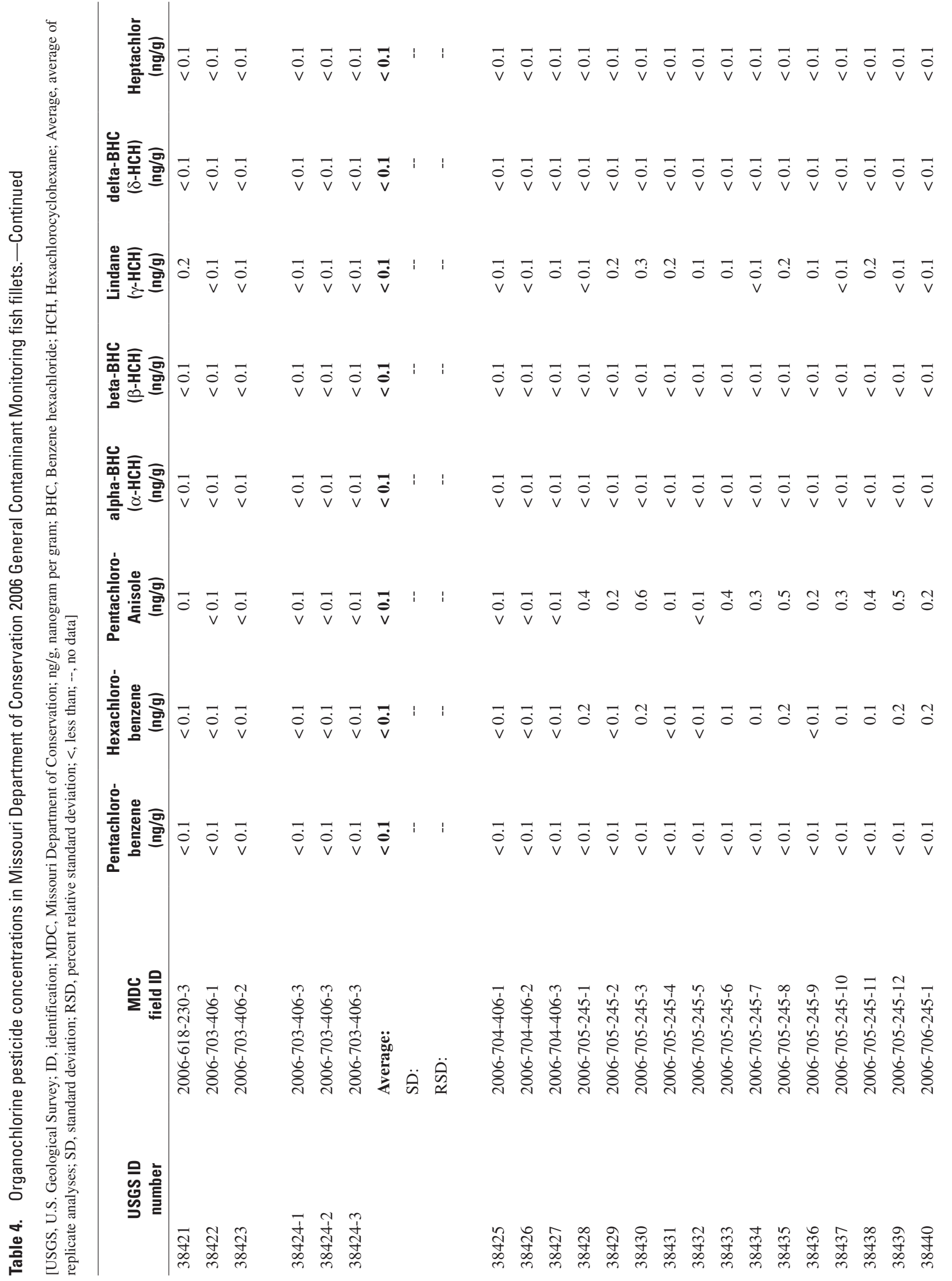




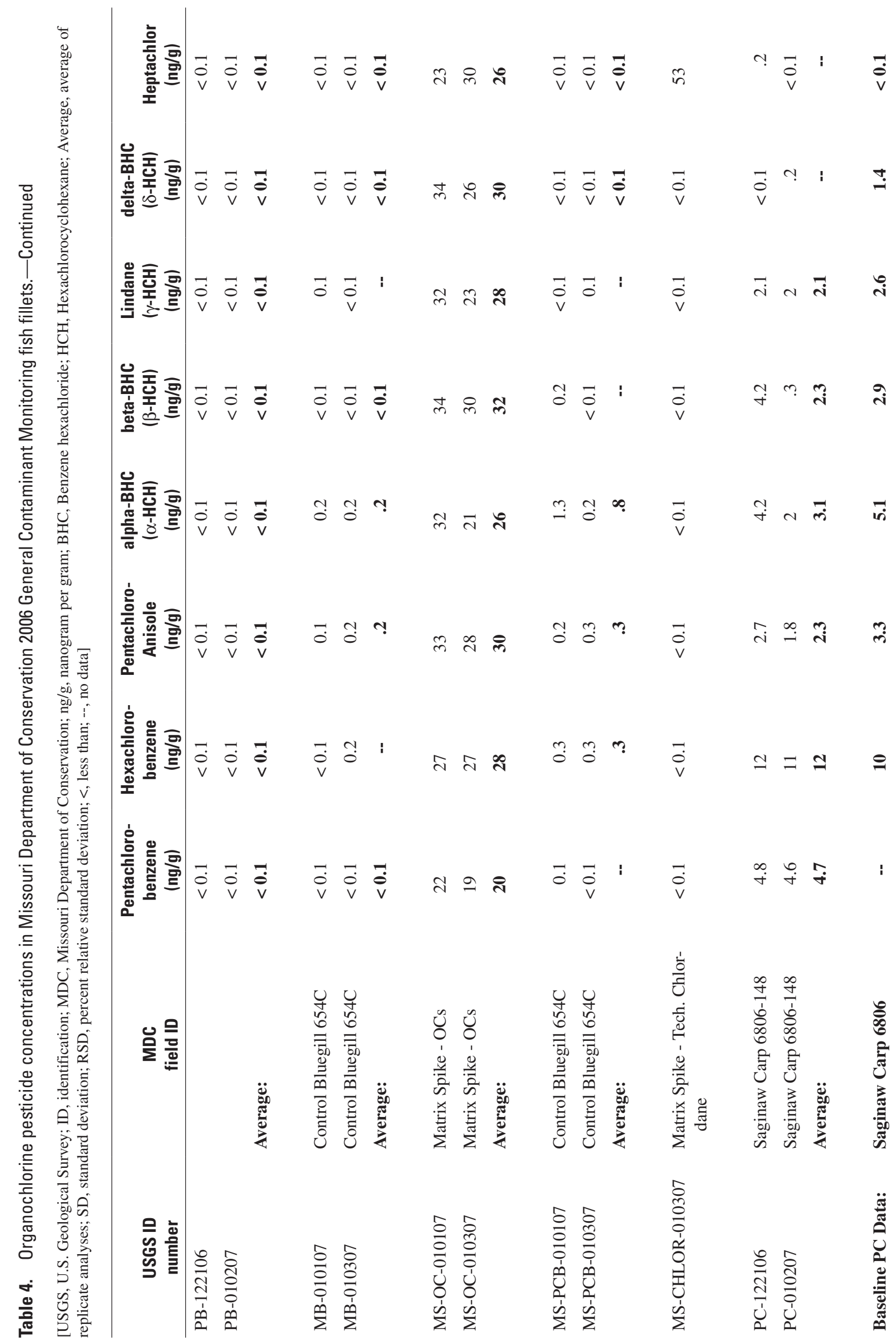




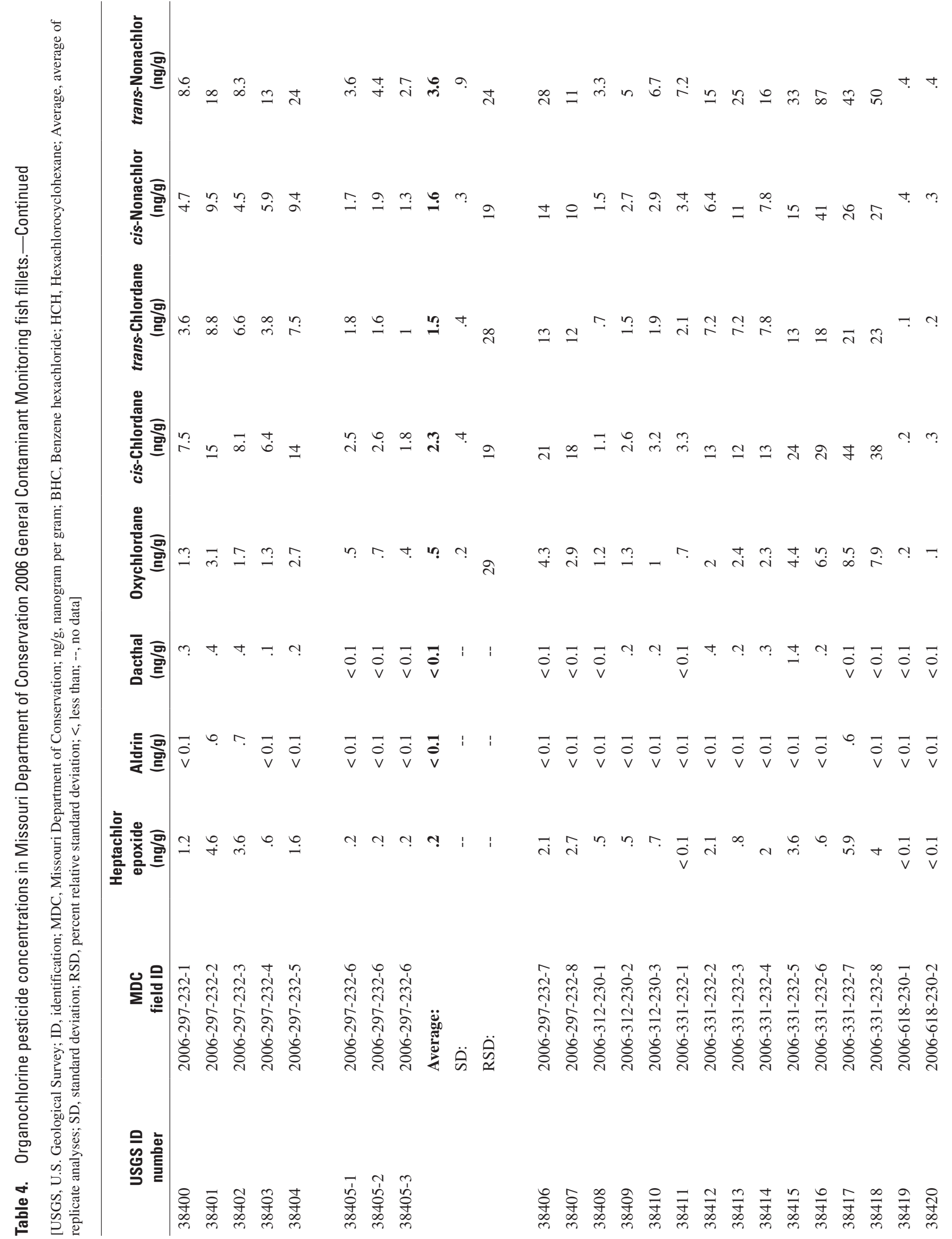




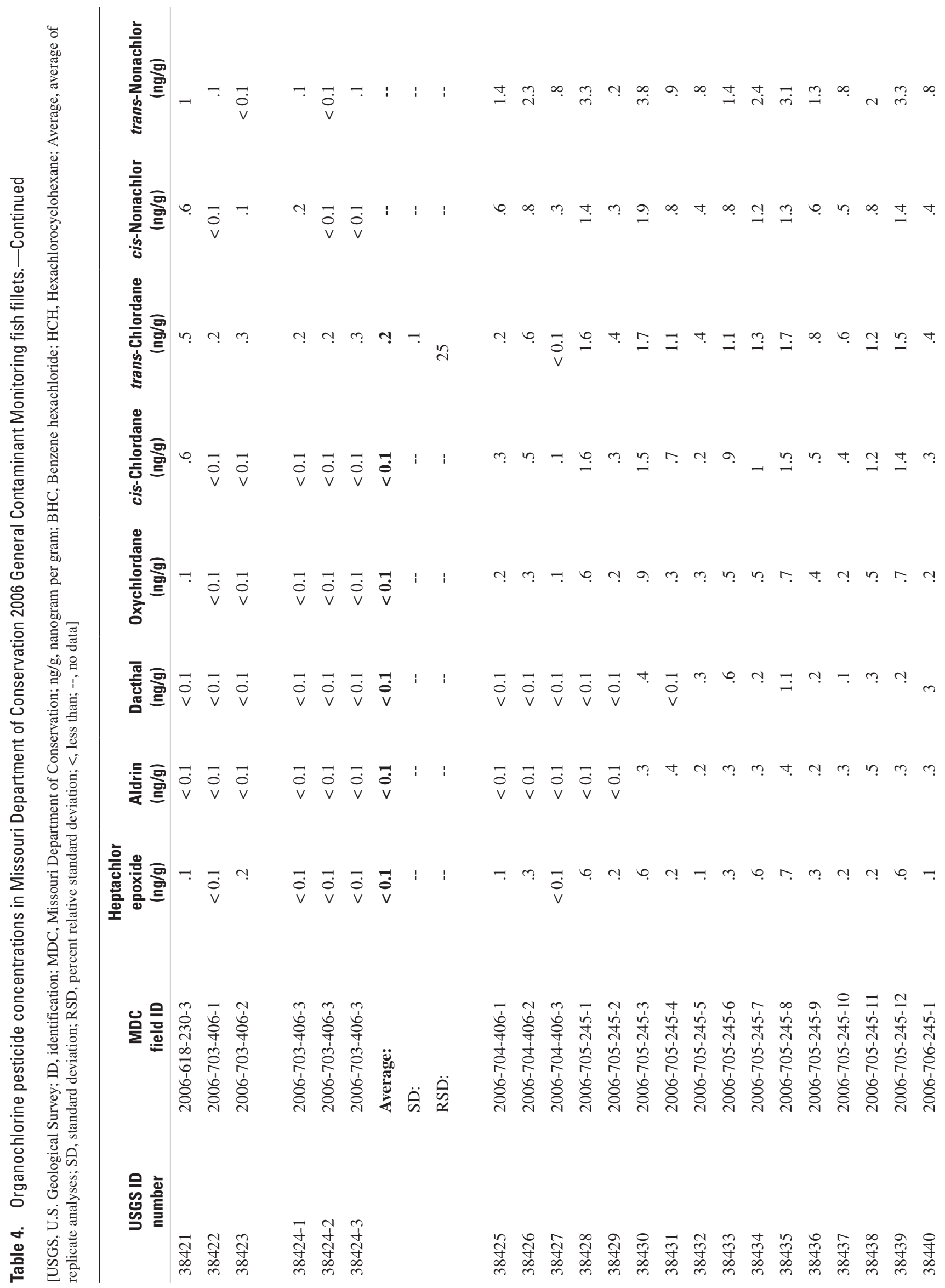




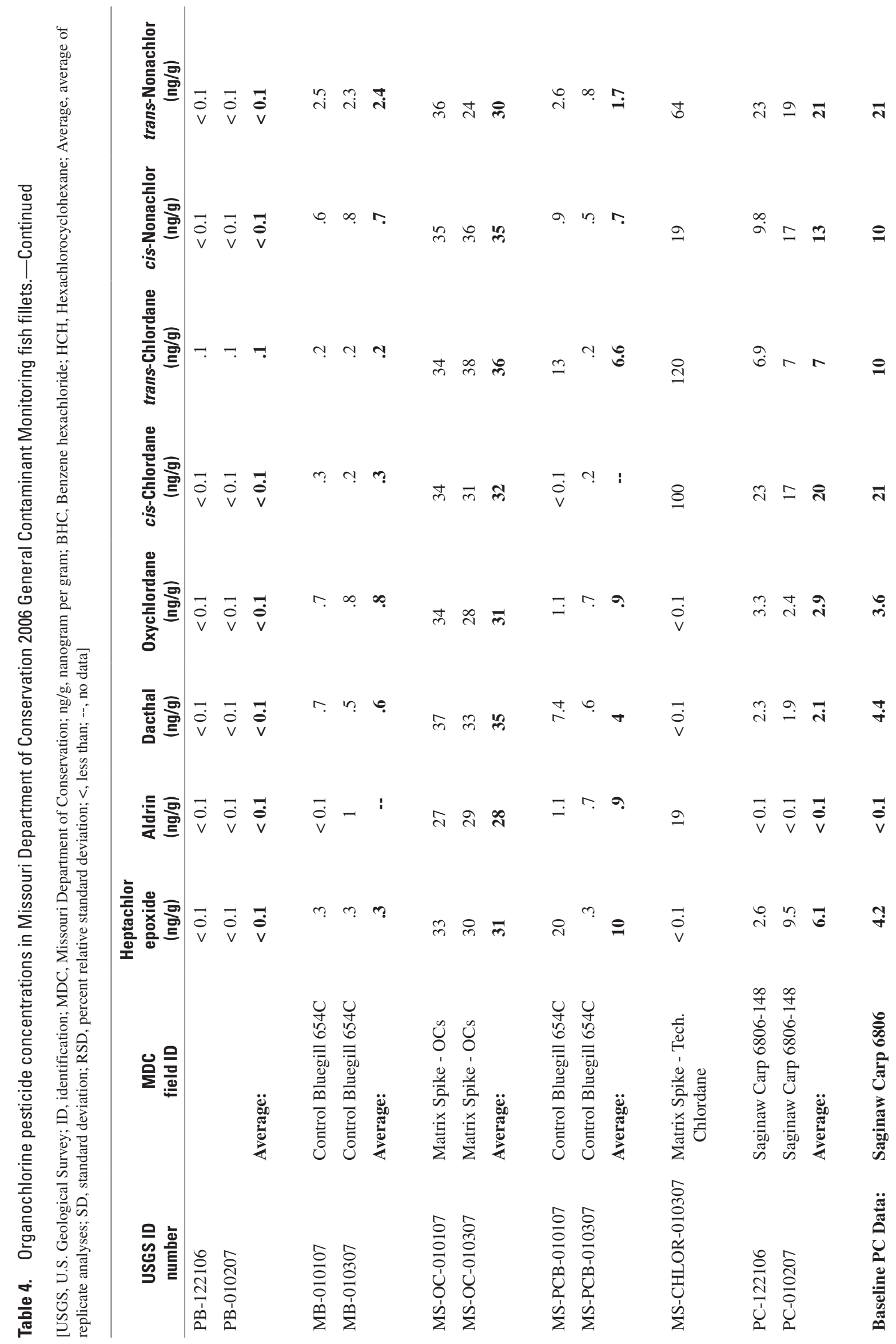




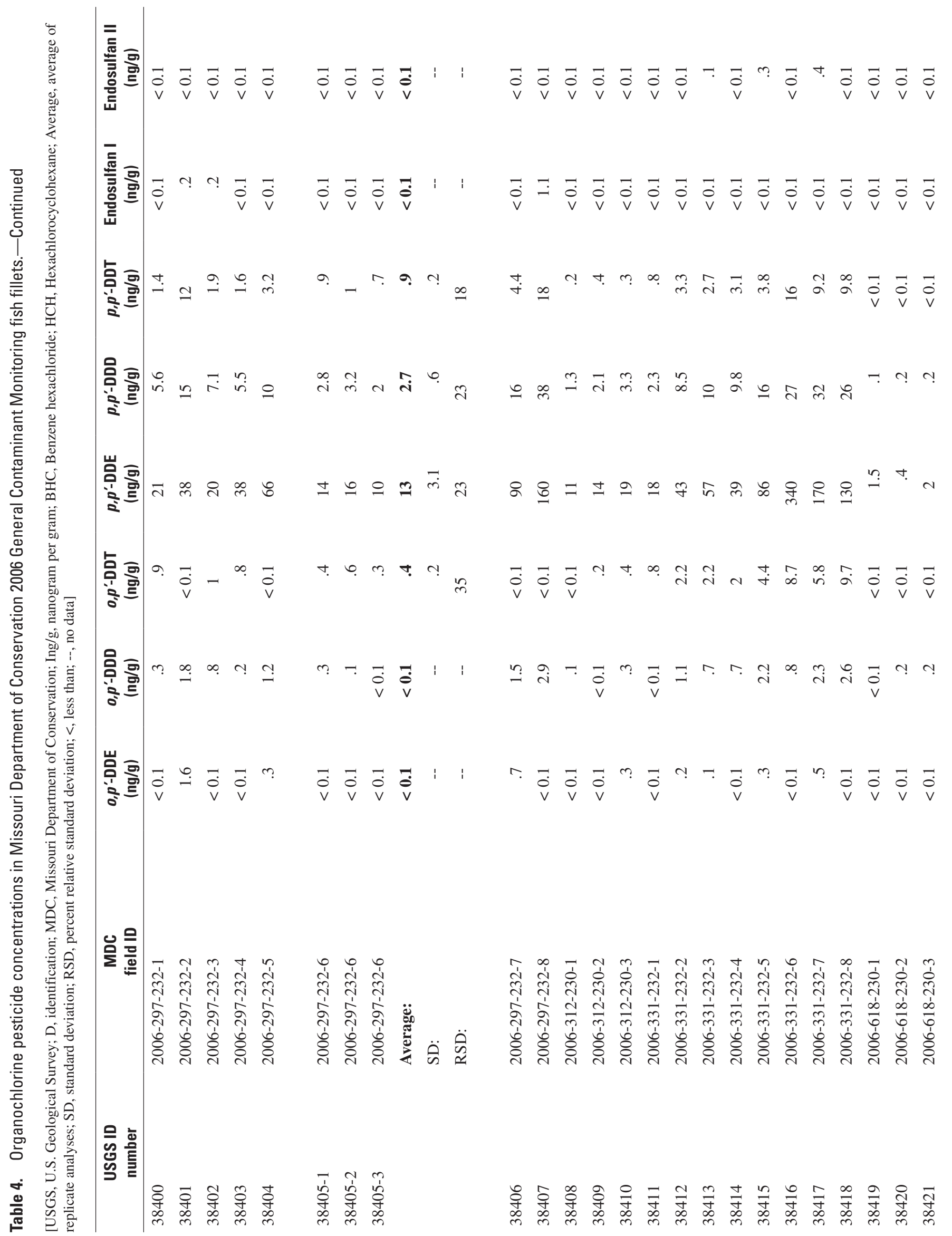




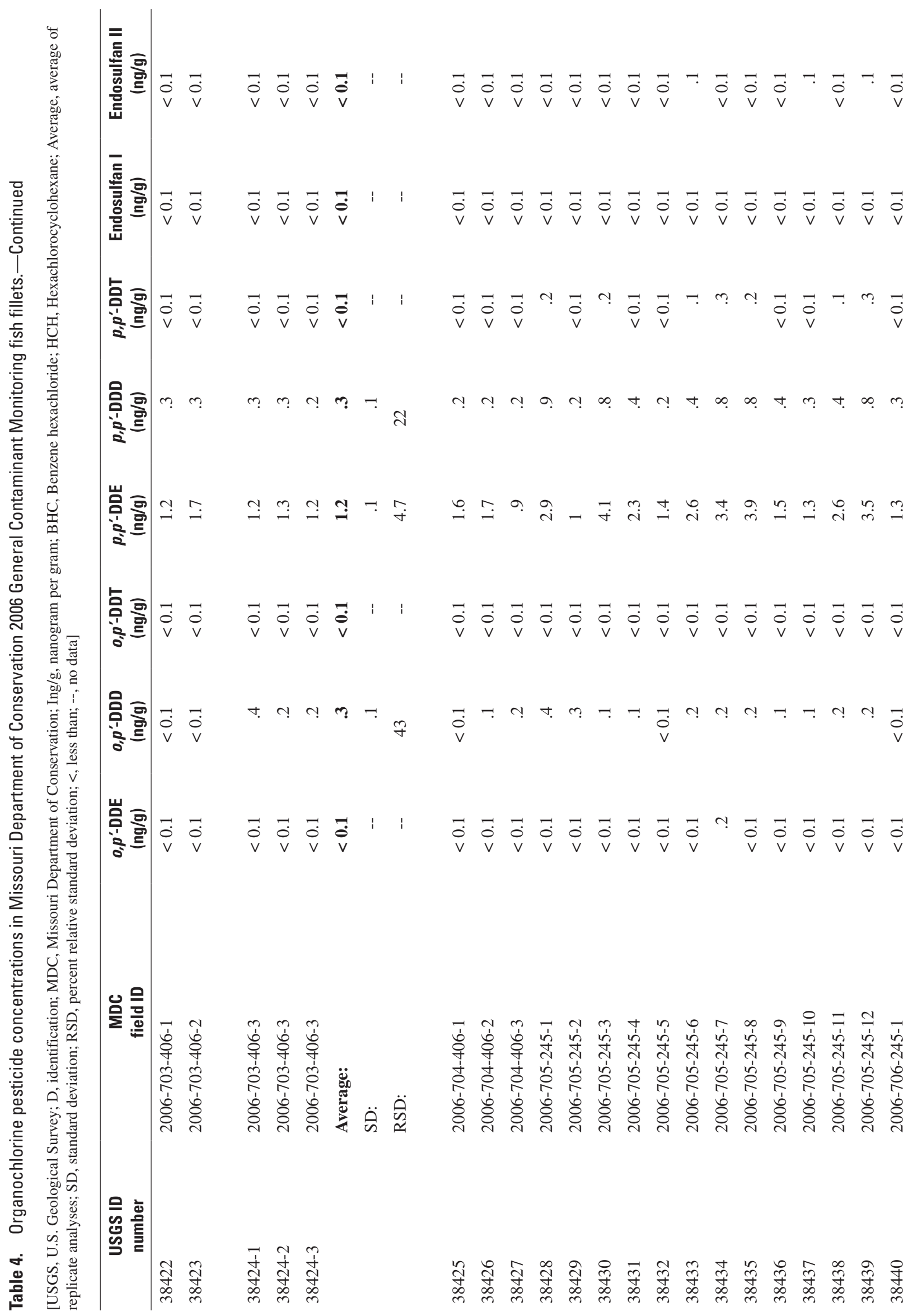




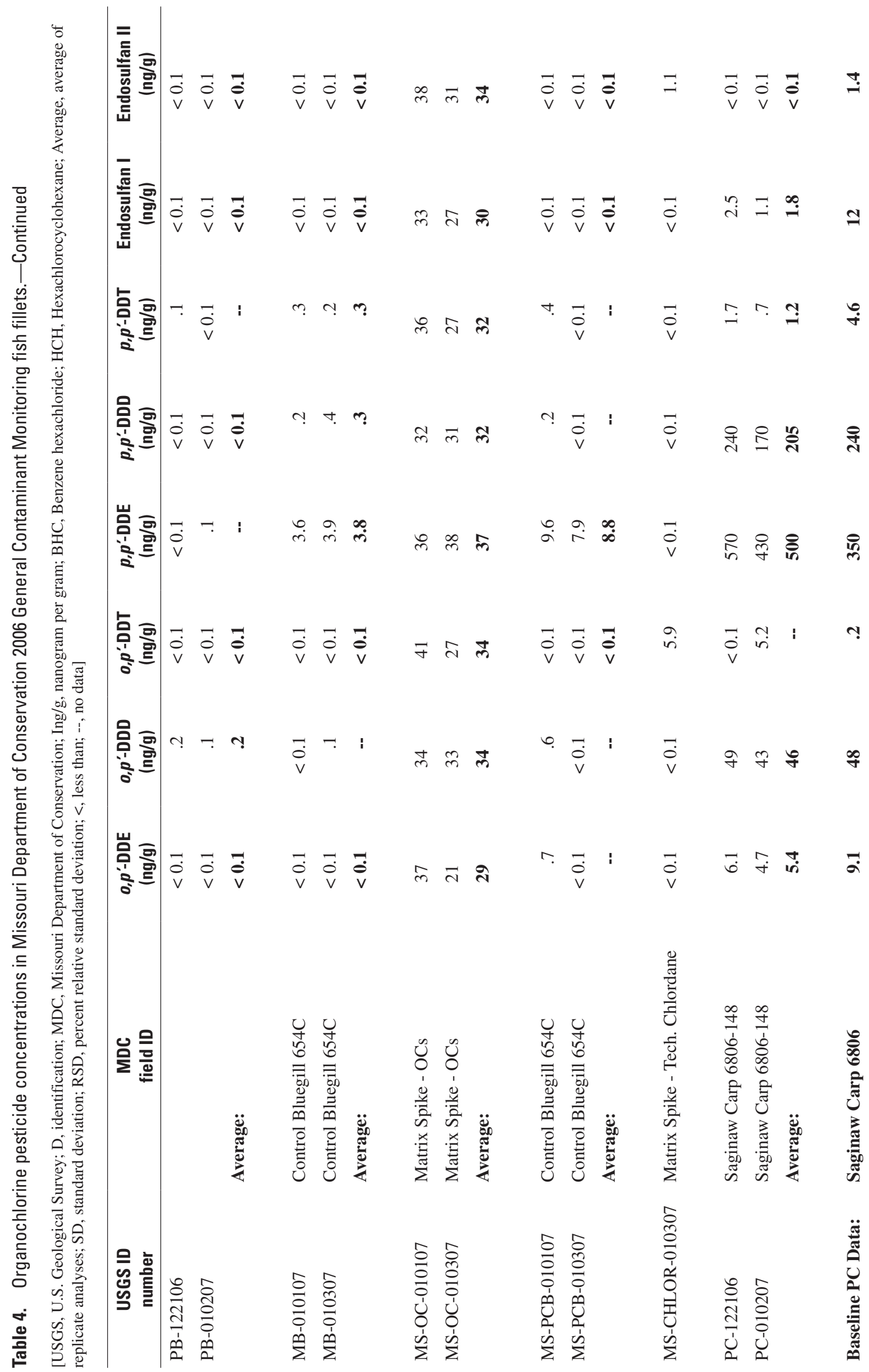




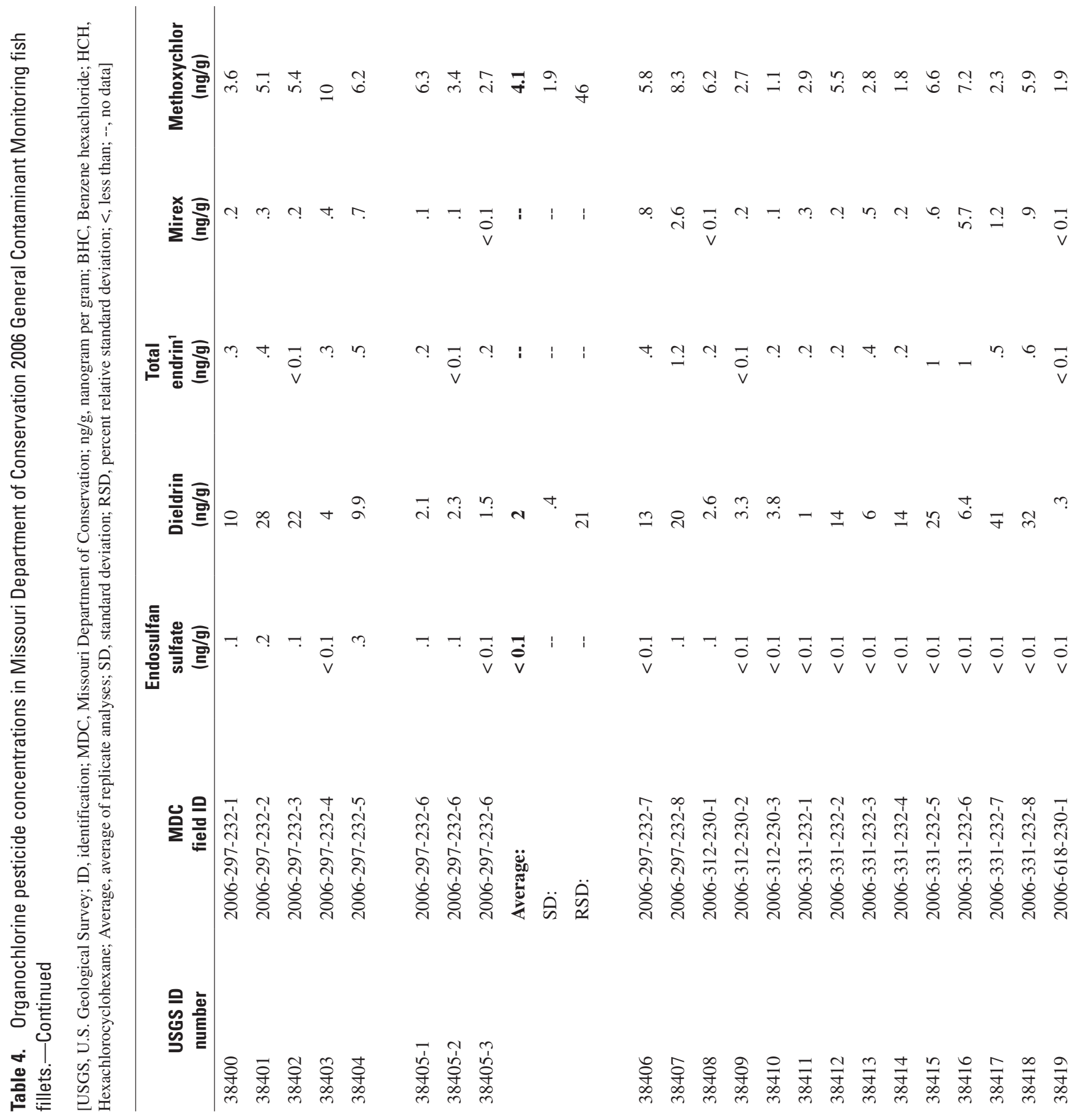




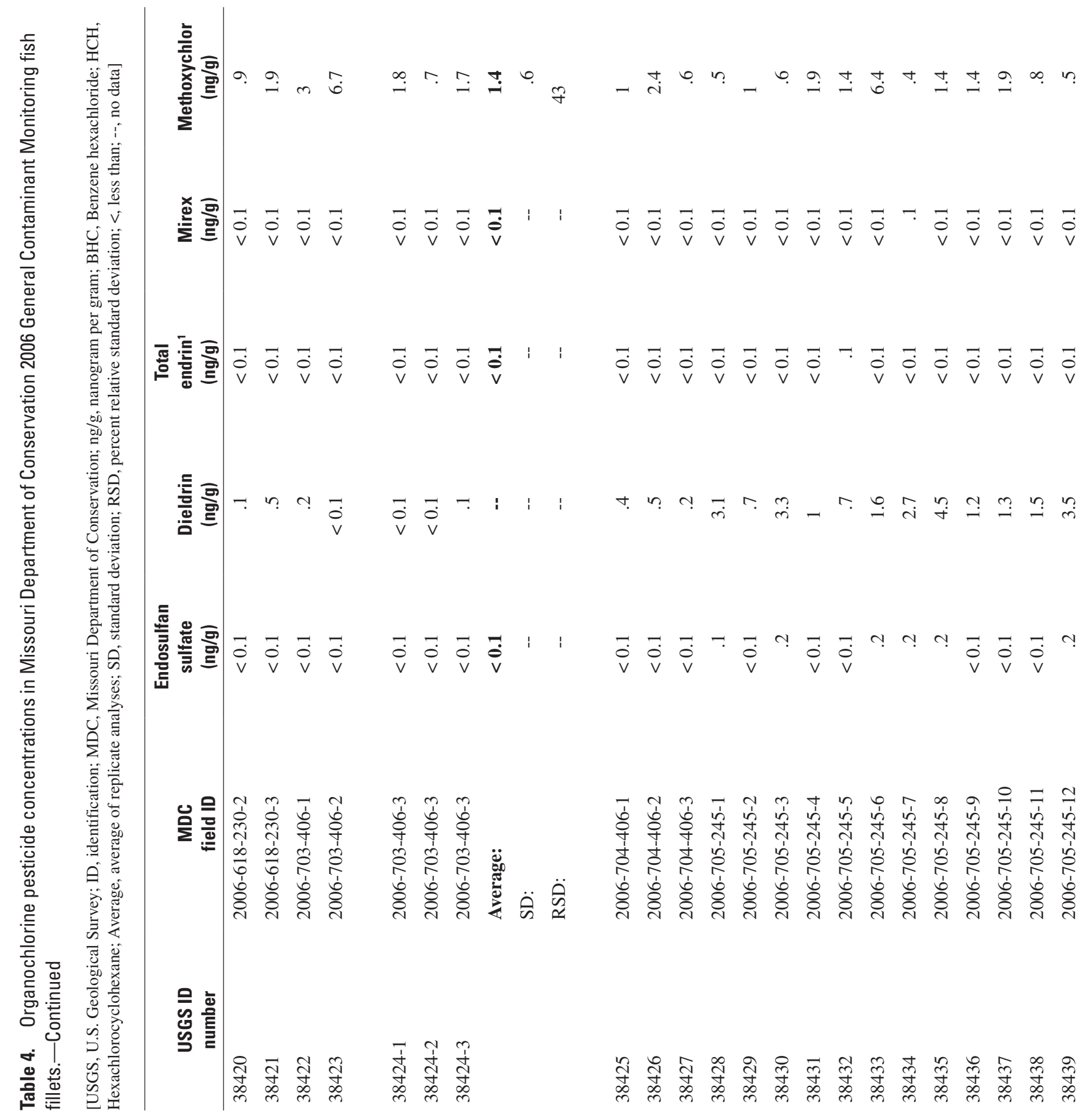




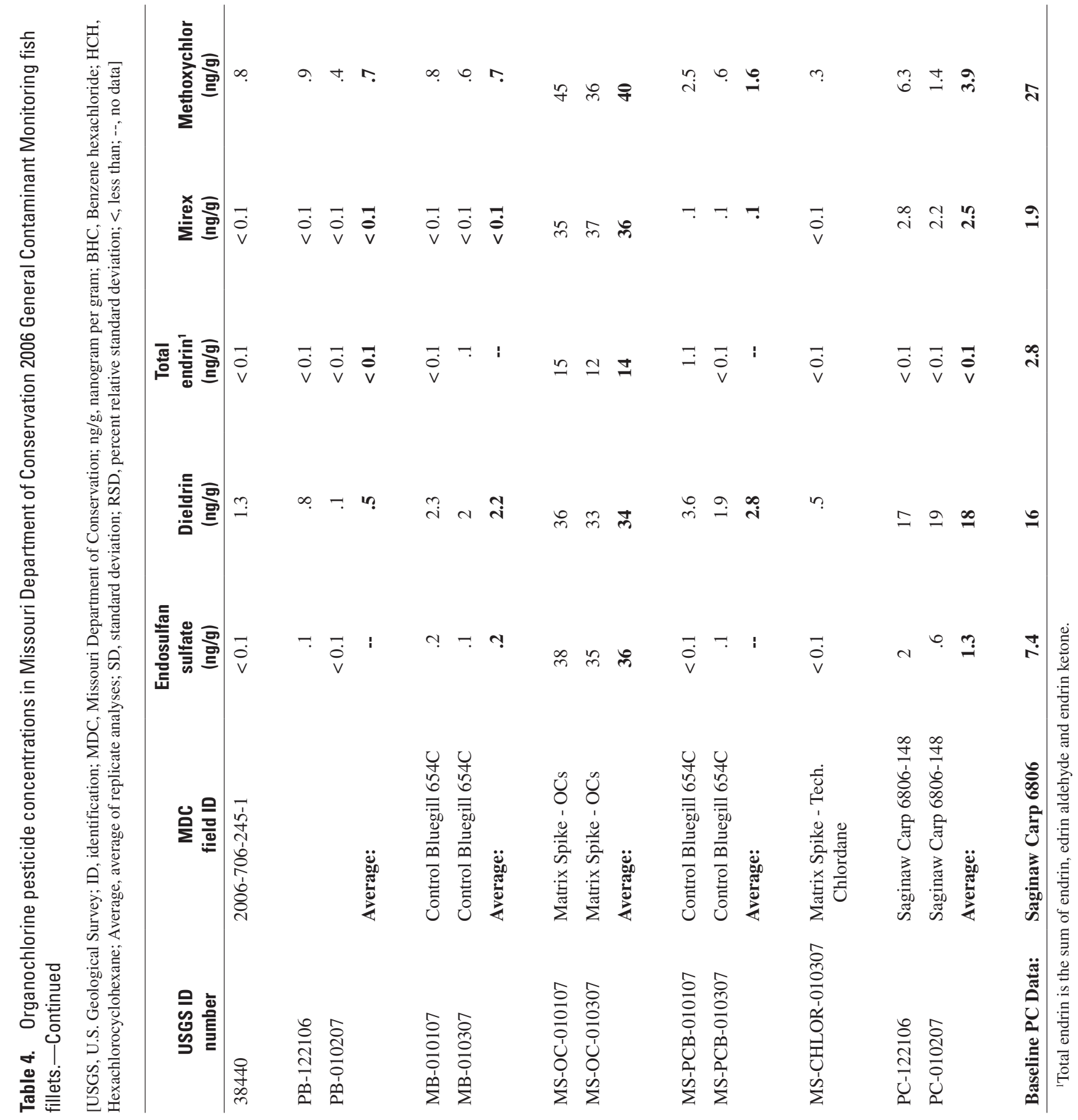


Table 5. Polybrominated diphenylethers concentrations and percentages in Missouri Department of Conservation 2006 General Contaminant Monitoring fish fillets.

[USGS, U.S. Geological Survey; ID, identification; MDC, Missouri Department of Conservation; PBDE, Polybrominated Diphenylether; ng/g, nanogram per gram; Average, average of replicate analyses; SD, standard deviation; RSD, percent relative standard deviation; --, no data. No historic data exists for PBDEs in Postive Control Saginaw Bay Carp]

\begin{tabular}{|c|c|c|c|c|c|c|c|}
\hline \multirow{2}{*}{$\begin{array}{c}\text { USGS ID } \\
\text { number }\end{array}$} & \multirow{2}{*}{$\begin{array}{c}\text { MDC } \\
\text { field ID }\end{array}$} & \multicolumn{2}{|c|}{ PBDE-028 } & \multicolumn{2}{|c|}{ PBDE-047 } & \multicolumn{2}{|c|}{ PBDE-066 } \\
\hline & & (ng/g) & (percent) & $(\mathrm{ng} / \mathrm{g})$ & (percent) & $(\mathrm{ng} / \mathrm{g})$ & (percent) \\
\hline 38400 & 2006-297-232-1 & $<0.2$ & & 14 & 48 & $<0.2$ & \\
\hline 38402 & $2006-297-232-3$ & .8 & 2 & 14 & 43 & $<0.2$ & \\
\hline 38403 & 2006-297-232-4 & $<0.2$ & & 23 & 53 & $<0.2$ & \\
\hline $38405-1$ & $2006-297-232-6$ & $<0.2$ & & 7.9 & 50 & $<0.2$ & \\
\hline $38405-2$ & $2006-297-232-6$ & $<0.2$ & & 8.6 & 50 & $<0.2$ & \\
\hline $38405-3$ & $2006-297-232-6$ & $<0.2$ & & 6.2 & 48 & $<0.2$ & \\
\hline 38406 & $2006-297-232-7$ & $<0.2$ & & 73 & 66 & $<0.2$ & \\
\hline 38407 & $2006-297-232-8$ & $<0.2$ & & 33 & 68 & $<0.2$ & \\
\hline 38408 & 2006-312-230-1 & $<0.2$ & & 4.8 & 42 & $<0.2$ & \\
\hline 38409 & $2006-312-230-2$ & $<0.2$ & & 8.6 & 52 & $<0.2$ & \\
\hline 38410 & $2006-312-230-3$ & .4 & 2 & 14 & 60 & .3 & 1 \\
\hline 38411 & $2006-331-232-1$ & .9 & 2 & 30 & 60 & .7 & 1 \\
\hline 38412 & $2006-331-232-2$ & 2.3 & 4 & 34 & 58 & .9 & 2 \\
\hline 38419 & 2006-618-230-1 & .3 & 6 & 1.7 & 35 & .4 & 8 \\
\hline 38420 & $2006-618-230-2$ & $<0.2$ & & 2.3 & 32 & $<0.2$ & \\
\hline 38421 & $2006-618-230-3$ & .3 & 4 & 2.7 & 36 & $<0.2$ & \\
\hline 38422 & $2006-703-406-1$ & $<0.2$ & & 1.8 & 42 & $<0.2$ & \\
\hline 38423 & $2006-703-406-2$ & $<0.2$ & & 1.6 & 44 & $<0.2$ & \\
\hline $38424-1$ & $2006-703-406-3$ & $<0.2$ & & 1.8 & 30 & $<0.2$ & \\
\hline $38424-2$ & $2006-703-406-3$ & $<0.2$ & & 1.8 & 38 & $<0.2$ & \\
\hline \multirow[t]{4}{*}{$38424-3$} & $2006-703-406-3$ & .3 & 7 & 1.5 & 37 & $<0.2$ & \\
\hline & Average: & -- & & 1.7 & 35 & $<0.2$ & \\
\hline & SD: & -- & & .2 & 4 & -- & \\
\hline & RSD: & -- & & 10 & 12 & -- & \\
\hline
\end{tabular}


Table 5. Polybrominated diphenylethers concentrations and percentages in Missouri Department of Conservation 2006 General Contaminant Monitoring fish fillets. - Continued

[USGS, U.S. Geological Survey; ID, identification; MDC, Missouri Department of Conservation; PBDE, Polybrominated Diphenylether; ng/g, nanogram per gram; Average, average of replicate analyses; SD, standard deviation; RSD, percent relative standard deviation; --, no data. No historic data exists for PBDEs in Postive Control Saginaw Bay Carp]

\begin{tabular}{|c|c|c|c|c|c|c|c|}
\hline \multirow{2}{*}{$\begin{array}{l}\text { USGS ID } \\
\text { number }\end{array}$} & \multirow{2}{*}{$\begin{array}{l}\text { MDC } \\
\text { field ID }\end{array}$} & \multicolumn{2}{|c|}{ PBDE-028 } & \multicolumn{2}{|c|}{ PBDE-047 } & \multicolumn{2}{|c|}{ PBDE-066 } \\
\hline & & $(\mathrm{ng} / \mathrm{g})$ & (percent) & $(\mathrm{ng} / \mathrm{g})$ & (percent) & $(\mathrm{ng} / \mathrm{g})$ & (percent) \\
\hline 38425 & 2006-704-406-1 & .3 & 9 & 1.3 & 39 & $<0.2$ & \\
\hline 38426 & 2006-704-406-2 & .3 & 9 & 1.4 & 41 & $<0.2$ & \\
\hline 38427 & $2006-704-406-3$ & $<0.2$ & & 1.2 & 41 & $<0.2$ & \\
\hline 38428 & $2006-705-245-1$ & $<0.2$ & & 5.5 & 45 & $<0.2$ & \\
\hline 38429 & $2006-705-245-2$ & $<0.2$ & & 1.4 & 48 & $<0.2$ & \\
\hline 38430 & $2006-705-245-3$ & $<0.2$ & & 7.7 & 55 & $<0.2$ & \\
\hline 38431 & $2006-705-245-4$ & .2 & 2 & 5.3 & 48 & $<0.2$ & \\
\hline 38432 & $2006-705-245-5$ & .3 & 4 & 3 & 44 & $<0.2$ & \\
\hline 38433 & $2006-705-245-6$ & .4 & 4 & 5.2 & 55 & $<0.2$ & \\
\hline 38434 & $2006-705-245-7$ & $<0.2$ & & 5.3 & 52 & $<0.2$ & \\
\hline 38435 & $2006-705-245-8$ & .3 & 2 & 6.3 & 47 & $<0.2$ & \\
\hline 38436 & $2006-705-245-9$ & .3 & 3 & 4.2 & 39 & $<0.2$ & \\
\hline 38437 & $2006-705-245-10$ & $<0.2$ & & 2.8 & 42 & $<0.2$ & \\
\hline 38438 & 2006-705-245-11 & .4 & 4 & 5.5 & 49 & $<0.2$ & \\
\hline 38439 & $2006-705-245-12$ & $<0.2$ & & 6 & 57 & $<0.2$ & \\
\hline 38440 & 2006-706-245-1 & $<0.2$ & & 3.3 & 47 & $<0.2$ & \\
\hline PB-122106 & & $<0.2$ & & 2.9 & 37 & $<0.2$ & \\
\hline \multirow[t]{2}{*}{ PB-010207 } & & .3 & 8 & 1.6 & 42 & $<0.2$ & \\
\hline & Average: & -- & & 2.2 & 38 & $<0.2$ & \\
\hline MB-010107 & Control Bluegill 654C & .4 & 3 & 4.9 & 41 & .5 & 4 \\
\hline \multirow[t]{2}{*}{ MB-010307 } & Control Bluegill 654C & .2 & 2 & 4 & 38 & $<0.2$ & \\
\hline & Average: & .3 & 3 & 4.5 & 40 & -- & \\
\hline MS-PCB-010107 & Control Bluegill 654C & .3 & 3 & 3 & 29 & .6 & 6 \\
\hline \multirow[t]{2}{*}{ MS-PCB-010307 } & Control Bluegill 654C & $<0.2$ & & 1.8 & 47 & $<0.2$ & \\
\hline & Average: & -- & & 2.4 & 38 & -- & \\
\hline MS-CHLOR-010307 & $\begin{array}{l}\text { Matrix Spike - Tech. } \\
\text { Chlordane }\end{array}$ & 4.9 & 31 & $<0.2$ & & $<0.2$ & \\
\hline PC-122106 & $\begin{array}{l}\text { Saginaw Carp } \\
\text { 6806-148 }\end{array}$ & $<0.2$ & & 4.5 & 47 & $<0.2$ & \\
\hline \multirow[t]{2}{*}{ PC-010207 } & $\begin{array}{l}\text { Saginaw Carp } \\
\quad 6806-148\end{array}$ & $<0.2$ & & 5.8 & 60 & $<0.2$ & \\
\hline & Average: & $<0.2$ & & 5.1 & 53 & $<0.2$ & \\
\hline
\end{tabular}


Table 5. Polybrominated diphenylethers concentrations and percentages in Missouri Department of Conservation 2006 General Contaminant Monitoring fish fillets.-Continued

[USGS, U.S. Geological Survey; ID, identification; MDC, Missouri Department of Conservation; PBDE, Polybrominated Diphenylether; ng/g, nanogram per gram; Average, average of replicate analyses; SD, standard deviation; RSD, percent relative standard deviation; --, no data. No historic data exists for PBDEs in Postive Control Saginaw Bay Carp]

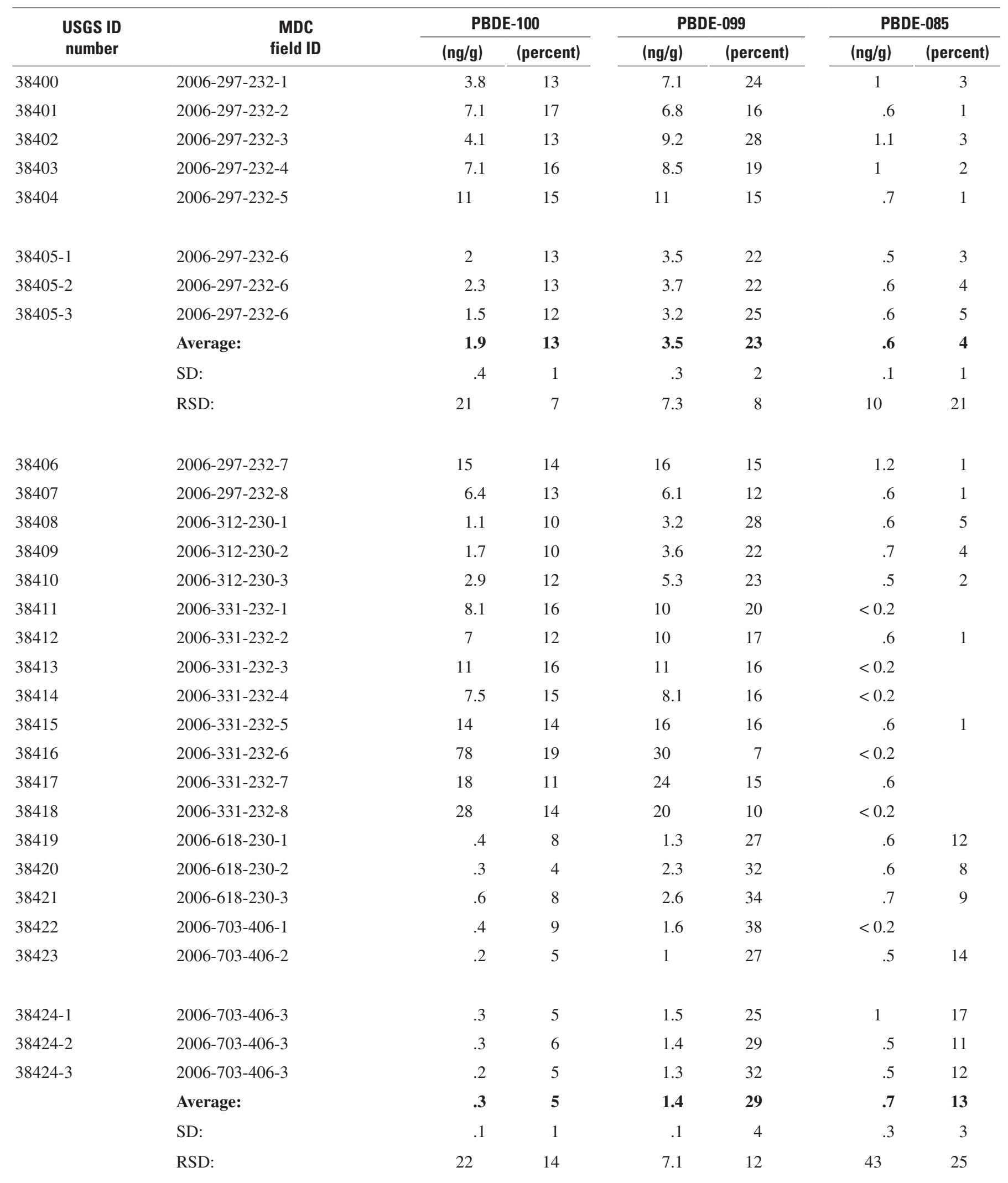


Table 5. Polybrominated diphenylethers concentrations and percentages in Missouri Department of Conservation 2006 General Contaminant Monitoring fish fillets. - Continued

[USGS, U.S. Geological Survey; ID, identification; MDC, Missouri Department of Conservation; PBDE, Polybrominated Diphenylether; ng/g, nanogram per gram; Average, average of replicate analyses; SD, standard deviation; RSD, percent relative standard deviation; --, no data. No historic data exists for PBDEs in Postive Control Saginaw Bay Carp]

\begin{tabular}{|c|c|c|c|c|c|c|c|}
\hline \multirow{2}{*}{$\begin{array}{l}\text { USGS ID } \\
\text { number }\end{array}$} & \multirow{2}{*}{$\begin{array}{l}\text { MDC } \\
\text { field ID }\end{array}$} & \multicolumn{2}{|c|}{ PBDE-100 } & \multicolumn{2}{|c|}{ PBDE-099 } & \multicolumn{2}{|c|}{ PBDE-085 } \\
\hline & & $(\mathbf{n g} / \mathbf{g})$ & (percent) & $(\mathbf{n g} / \mathbf{g})$ & (percent) & $(\mathrm{ng} / \mathrm{g})$ & (percent) \\
\hline 38425 & 2006-704-406-1 & .3 & 9 & .9 & 27 & .5 & 15 \\
\hline 38426 & $2006-704-406-2$ & .3 & 9 & 1.1 & 32 & $<0.2$ & \\
\hline 38427 & $2006-704-406-3$ & $<0.2$ & & .9 & 31 & .5 & 17 \\
\hline 38428 & 2006-705-245-1 & 1.3 & 11 & 3.1 & 25 & .6 & 5 \\
\hline 38429 & $2006-705-245-2$ & $<0.2$ & & .8 & 27 & .5 & 17 \\
\hline 38430 & $2006-705-245-3$ & 1.8 & 13 & 3.9 & 28 & .6 & 4 \\
\hline 38431 & $2006-705-245-4$ & .9 & 8 & 4.2 & 38 & $<0.2$ & \\
\hline 38432 & $2006-705-245-5$ & .7 & 10 & 2.7 & 39 & $<0.2$ & \\
\hline 38433 & $2006-705-245-6$ & 1 & 11 & 2.9 & 31 & $<0.2$ & \\
\hline 38434 & $2006-705-245-7$ & 1.1 & 11 & 2.4 & 23 & .6 & 6 \\
\hline 38435 & $2006-705-245-8$ & 1.4 & 11 & 4.1 & 31 & .6 & 5 \\
\hline 38436 & 2006-705-245-9 & 1.1 & 10 & 4.2 & 39 & $<0.2$ & \\
\hline 38437 & $2006-705-245-10$ & .6 & 9 & 2.1 & 32 & .6 & 9 \\
\hline 38438 & 2006-705-245-11 & 1.2 & 11 & 4.1 & 36 & $<0.2$ & \\
\hline 38439 & $2006-705-245-12$ & 1.3 & 12 & 3.3 & 31 & $<0.2$ & \\
\hline 38440 & $2006-706-245-1$ & .6 & 9 & 2 & 29 & .6 & 9 \\
\hline PB-122106 & & .5 & 6 & 3.1 & 39 & .8 & 10 \\
\hline \multirow[t]{2}{*}{ PB-010207 } & & $<0.2$ & & 1.2 & 32 & $<0.2$ & \\
\hline & Average: & -- & & 2.2 & 38 & -- & \\
\hline MB-010107 & Control Bluegill 654C & .8 & 7 & 4.3 & 36 & $<0.2$ & \\
\hline \multirow[t]{2}{*}{ MB-010307 } & Control Bluegill 654C & .5 & 5 & 3.8 & 36 & .6 & 6 \\
\hline & Average: & .7 & 6 & 4.1 & 37 & -- & \\
\hline MS-PCB-010107 & Control Bluegill 654C & .3 & 3 & 1.4 & 13 & 2 & 19 \\
\hline \multirow[t]{2}{*}{ MS-PCB-010307 } & Control Bluegill 654C & $<0.2$ & & 1.7 & 44 & $<0.2$ & \\
\hline & Average: & -- & & 1.5 & 27 & -- & \\
\hline MS-CHLOR-010307 & Matrix Spike - Tech. Chlordane & 1.4 & 9 & 7.3 & 46 & .8 & 5 \\
\hline PC-122106 & Saginaw Carp 6806-148 & .7 & 7 & 2.2 & 23 & .8 & 8 \\
\hline \multirow[t]{2}{*}{ PC-010207 } & Saginaw Carp 6806-148 & .9 & 9 & 2.9 & 30 & $<0.2$ & \\
\hline & Average: & .8 & 8 & 2.5 & 26 & -- & \\
\hline
\end{tabular}


Table 5. Polybrominated diphenylethers concentrations and percentages in Missouri Department of Conservation 2006 General Contaminant Monitoring fish fillets.-Continued

[USGS, U.S. Geological Survey; MDC, Missouri Department of Conservation; ID, identification; PBDE, Polybrominated Diphenylether; ng/g, nanogram per gram; Average, average of replicate analyses; SD, standard deviation; RSD, percent relative standard deviation; --, no data. No historic data exists for PBDEs in Postive Control Saginaw Bay Carp]

\begin{tabular}{|c|c|c|c|c|c|c|c|c|}
\hline \multirow{2}{*}{$\begin{array}{l}\text { USGS ID } \\
\text { number }\end{array}$} & \multirow{2}{*}{$\begin{array}{l}\text { MDC } \\
\text { field ID }\end{array}$} & \multicolumn{2}{|c|}{ PBDE-154 } & \multicolumn{2}{|c|}{ PBDE-153 } & \multicolumn{2}{|c|}{ PBDE-183 } & \multirow{2}{*}{$\begin{array}{c}\text { Total PBDE } \\
\text { (ng/g) }\end{array}$} \\
\hline & & $(\mathbf{n g} / \mathbf{g})$ & (percent) & (ng/g) & (percent) & (ng/g) & (percent) & \\
\hline 38400 & 2006-297-232-1 & 1.4 & 5 & 1.4 & 5 & .3 & 1 & 29 \\
\hline 38401 & $2006-297-232-2$ & 1.4 & 3 & 1.6 & 4 & $<0.2$ & & 43 \\
\hline 38402 & $2006-297-232-3$ & 1.4 & 4 & 1.7 & 5 & $<0.2$ & & 33 \\
\hline 38403 & $2006-297-232-4$ & 2.4 & 6 & 1.4 & 3 & $<0.2$ & & 44 \\
\hline 38404 & $2006-297-232-5$ & 3.9 & 5 & 1.7 & 2 & $<0.2$ & & 72 \\
\hline $38405-1$ & $2006-297-232-6$ & .8 & 5 & 1.1 & 7 & $<0.2$ & & 16 \\
\hline $38405-2$ & $2006-297-232-6$ & 1 & 6 & .8 & 5 & $<0.2$ & & 17 \\
\hline \multirow[t]{4}{*}{$38405-3$} & $2006-297-232-6$ & .6 & 5 & .7 & 5 & $<0.2$ & & 13 \\
\hline & Average: & .8 & 5 & .9 & 6 & $<0.2$ & & 15 \\
\hline & SD: & .2 & 1 & .2 & 1 & & & 2 \\
\hline & RSD: & 25 & 12 & 24 & 20 & & & 14 \\
\hline 38406 & $2006-297-232-7$ & 2.7 & 2 & 2.1 & 2 & $<0.2$ & & 110 \\
\hline 38407 & $2006-297-232-8$ & 1.4 & 3 & 1.1 & 2 & $<0.2$ & & 49 \\
\hline 38408 & $2006-312-230-1$ & .8 & 7 & .7 & 6 & $<0.2$ & & 11 \\
\hline 38409 & $2006-312-230-2$ & .8 & 5 & .9 & 5 & $<0.2$ & & 16 \\
\hline 38410 & $2006-312-230-3$ & $<0.2$ & & $<0.2$ & & $<0.2$ & & 23 \\
\hline 38411 & $2006-331-232-1$ & $<0.2$ & & .2 & & $<0.2$ & & 50 \\
\hline 38412 & $2006-331-232-2$ & 1.6 & 3 & 2.1 & 4 & $<0.2$ & & 59 \\
\hline 38413 & $2006-331-232-3$ & $<0.2$ & & $<0.2$ & & $<0.2$ & & 69 \\
\hline 38414 & $2006-331-232-4$ & $<0.2$ & & .2 & & $<0.2$ & & 52 \\
\hline 38415 & $2006-331-232-5$ & $<0.2$ & & $<0.2$ & & $<0.2$ & & 102 \\
\hline 38416 & $2006-331-232-6$ & $<0.2$ & & .4 & & $<0.2$ & & 410 \\
\hline 38417 & $2006-331-232-7$ & $<0.2$ & & $<0.2$ & & $<0.2$ & & 162 \\
\hline 38418 & $2006-331-232-8$ & $<0.2$ & & .3 & & .3 & .2 & 195 \\
\hline 38419 & 2006-618-230-1 & $<0.2$ & & $<0.2$ & & $<0.2$ & & 5 \\
\hline 38420 & $2006-618-230-2$ & .5 & 7 & 1 & 14 & $<0.2$ & & 7 \\
\hline 38421 & $2006-618-230-3$ & .4 & 5 & .2 & 3 & $<0.2$ & & 8 \\
\hline 38422 & 2006-703-406-1 & $<0.2$ & & .2 & 5 & $<0.2$ & & 4 \\
\hline 38423 & $2006-703-406-2$ & $<0.2$ & & $<0.2$ & & $<0.2$ & & 4 \\
\hline $38424-1$ & $2006-703-406-3$ & .5 & 8 & .7 & 12 & $<0.2$ & & 6 \\
\hline $38424-2$ & $2006-703-406-3$ & $<0.2$ & & .7 & 15 & $<0.2$ & & 5 \\
\hline \multirow[t]{4}{*}{ 38424-3 } & $2006-703-406-3$ & $<0.2$ & & $<0.2$ & & $<0.2$ & & 4 \\
\hline & Average: & -- & & -- & & $<0.2$ & & 5 \\
\hline & SD: & & & & & & & 1 \\
\hline & RSD: & & & & & & & 20 \\
\hline
\end{tabular}


Table 5. Polybrominated diphenylethers concentrations and percentages in Missouri Department of Conservation 2006 General Contaminant Monitoring fish fillets.-Continued

[USGS, U.S. Geological Survey; MDC, Missouri Department of Conservation; ID, identification; PBDE, Polybrominated Diphenylether; ng/g, nanogram per gram; Average, average of replicate analyses; SD, standard deviation; RSD, percent relative standard deviation; --, no data. No historic data exists for PBDEs in Postive Control Saginaw Bay Carp]

\begin{tabular}{|c|c|c|c|c|c|c|c|c|}
\hline \multirow{2}{*}{$\begin{array}{l}\text { USGS ID } \\
\text { number }\end{array}$} & \multirow{2}{*}{$\begin{array}{c}\text { MDC } \\
\text { field ID }\end{array}$} & \multicolumn{2}{|c|}{ PBDE-154 } & \multicolumn{2}{|c|}{ PBDE-153 } & \multicolumn{2}{|c|}{ PBDE-183 } & \multirow{2}{*}{$\begin{array}{l}\text { Total PBDE } \\
\text { (ng/g) }\end{array}$} \\
\hline & & (ng/g) & (percent) & $(\mathrm{ng} / \mathrm{g})$ & $\overline{\text { (percent) }}$ & (ng/g) & (percent) & \\
\hline 38425 & 2006-704-406-1 & $<0.2$ & & $<0.2$ & & $<0.2$ & & 3 \\
\hline 38426 & $2006-704-406-2$ & $<0.2$ & & .2 & 6 & $<0.2$ & & 3 \\
\hline 38427 & $2006-704-406-3$ & $<0.2$ & & $<0.2$ & & $<0.2$ & & 3 \\
\hline 38428 & $2006-705-245-1$ & .7 & 6 & .9 & 7 & $<0.2$ & & 12 \\
\hline 38429 & $2006-705-245-2$ & $<0.2$ & & $<0.2$ & & $<0.2$ & & 3 \\
\hline 38430 & $2006-705-245-3$ & $<0.2$ & & $<0.2$ & & $<0.2$ & & 14 \\
\hline 38431 & $2006-705-245-4$ & .4 & 4 & $<0.2$ & & $<0.2$ & & 11 \\
\hline 38432 & $2006-705-245-5$ & $<0.2$ & & $<0.2$ & & $<0.2$ & & 7 \\
\hline 38433 & $2006-705-245-6$ & $<0.2$ & & $<0.2$ & & $<0.2$ & & 9 \\
\hline 38434 & $2006-705-245-7$ & .6 & 6 & .2 & 2 & $<0.2$ & & 10 \\
\hline 38435 & $2006-705-245-8$ & $<0.2$ & & .3 & 2 & $<0.2$ & & 13 \\
\hline 38436 & $2006-705-245-9$ & .7 & 7 & $<0.2$ & & $<0.2$ & & 11 \\
\hline 38437 & 2006-705-245-10 & $<0.2$ & & $<0.2$ & & $<0.2$ & & 7 \\
\hline 38438 & 2006-705-245-11 & $<0.2$ & & $<0.2$ & & $<0.2$ & & 11 \\
\hline 38439 & 2006-705-245-12 & $<0.2$ & & $<0.2$ & & $<0.2$ & & 11 \\
\hline 38440 & 2006-706-245-1 & $<0.2$ & & $<0.2$ & & $<0.2$ & & 7 \\
\hline PB-122106 & & .2 & 3 & .3 & 4 & $<0.2$ & & 8 \\
\hline \multirow[t]{2}{*}{ PB-010207 } & & $<0.2$ & & .3 & 8 & $<0.2$ & & 4 \\
\hline & Average: & -- & & .3 & 5 & $<0.2$ & & 6 \\
\hline MB-010107 & Control Bluegill 654C & $<0.2$ & & .3 & 3 & .5 & 4.2 & 12 \\
\hline \multirow[t]{2}{*}{ MB-010307 } & Control Bluegill 654C & $<0.2$ & & $<0.2$ & & 1.1 & 10.4 & 11 \\
\hline & Average: & $<0.2$ & & -- & & .8 & 7.1 & 11 \\
\hline MS-PCB-010107 & Control Bluegill 654C & $<0.2$ & & .8 & 8 & 2 & 19 & 10 \\
\hline \multirow[t]{2}{*}{ MS-PCB-010307 } & Control Bluegill 654C & $<0.2$ & & $<0.2$ & & $<0.2$ & & 4 \\
\hline & Average: & $<0.2$ & & -- & & -- & & 6 \\
\hline MS-CHLOR-010307 & $\begin{array}{l}\text { Matrix Spike - Tech. } \\
\text { Chlordane }\end{array}$ & .7 & 4 & .8 & 5 & $<0.2$ & & 16 \\
\hline PC-122106 & $\begin{array}{l}\text { Saginaw Carp } \\
\text { 6806-148 }\end{array}$ & .6 & 6 & .6 & 6 & $<0.2$ & & 9 \\
\hline \multirow[t]{2}{*}{ PC-010207 } & $\begin{array}{l}\text { Saginaw Carp } \\
\text { 6806-148 }\end{array}$ & $<0.2$ & & $<0.2$ & & $<0.2$ & & 10 \\
\hline & Average: & -- & & -- & & $<0.2$ & & 10 \\
\hline
\end{tabular}


Table 6. Total chlordanes and summed target chlordane concentrations and percentages in Missouri Department of Conservation 2006 General Contaminant Monitoring fish fillets.

[USGS, U.S. Geological Survey; ID, identification; MDC, Missouri Department of Conservation; ng/g, nanogram per gram; Average, average of replicate analyses; SD, standard deviation; RSD, percent relative standard deviation; --, no data]

\begin{tabular}{|c|c|c|c|}
\hline $\begin{array}{l}\text { USGS ID } \\
\text { number }\end{array}$ & $\begin{array}{c}\text { MDC } \\
\text { field ID }\end{array}$ & $\begin{array}{c}\text { Total technical } \\
\text { chlordanes } \\
\text { (ng/g) }\end{array}$ & $\begin{array}{c}\text { Total target } \\
\text { chlordanes } \\
\text { (ng/g) }\end{array}$ \\
\hline 38400 & 2006-297-232-1 & 67 & 31 \\
\hline 38401 & $2006-297-232-2$ & 110 & 65 \\
\hline 38402 & $2006-297-232-3$ & 70 & 38 \\
\hline 38403 & $2006-297-232-4$ & 64 & 42 \\
\hline 38404 & $2006-297-232-5$ & 86 & 65 \\
\hline $38405-1$ & $2006-297-232-6$ & 30 & 17 \\
\hline $38405-2$ & $2006-297-232-6$ & 27 & 15 \\
\hline \multirow[t]{4}{*}{$38405-3$} & $2006-297-232-6$ & 21 & 10 \\
\hline & Average: & 26 & 14 \\
\hline & SD: & 4.6 & 3.6 \\
\hline & RSD: & 18 & 26 \\
\hline 38406 & $2006-297-232-7$ & 130 & 88 \\
\hline 38407 & $2006-297-232-8$ & 100 & 66 \\
\hline 38408 & 2006-312-230-1 & 19 & 15 \\
\hline 38409 & $2006-312-230-2$ & 28 & 16 \\
\hline 38410 & $2006-312-230-3$ & 22 & 17 \\
\hline 38411 & $2006-331-232-1$ & 25 & 20 \\
\hline 38412 & 2006-331-232-2 & 60 & 52 \\
\hline 38413 & $2006-331-232-3$ & 83 & 61 \\
\hline 38414 & $2006-331-232-4$ & 74 & 51 \\
\hline 38415 & $2006-331-232-5$ & 140 & 100 \\
\hline 38416 & $2006-331-232-6$ & 260 & 190 \\
\hline 38417 & $2006-331-232-7$ & 190 & 150 \\
\hline 38418 & $2006-331-232-8$ & 230 & 160 \\
\hline 38419 & 2006-618-230-1 & $<5$ & 3.2 \\
\hline 38420 & 2006-618-230-2 & 5.8 & 2.3 \\
\hline 38421 & 2006-618-230-3 & 9.1 & 5 \\
\hline 38422 & 2006-703-406-1 & $<5$ & 3.6 \\
\hline 38423 & 2006-703-406-2 & $<5$ & 7.5 \\
\hline
\end{tabular}


Table 6. Total chlordanes and summed target chlordane concentrations and percentages in Missouri Department of Conservation 2006 General Contaminant Monitoring fish fillets.-Continued

[USGS, U.S. Geological Survey; ID, identification; MDC, Missouri Department of Conservation; ng/g, nanogram per gram; Average, average of replicate analyses; SD, standard deviation; RSD, percent relative standard deviation; --, no data]

\begin{tabular}{|c|c|c|c|}
\hline $\begin{array}{l}\text { USGS ID } \\
\text { number }\end{array}$ & $\begin{array}{c}\text { MDC } \\
\text { field ID }\end{array}$ & $\begin{array}{c}\text { Total technical } \\
\text { chlordanes } \\
\text { (ng/g) }\end{array}$ & $\begin{array}{c}\text { Total target } \\
\text { chlordanes } \\
\text { (ng/g) }\end{array}$ \\
\hline $38424-1$ & $2006-703-406-3$ & $<5$ & 2.4 \\
\hline $38424-2$ & $2006-703-406-3$ & $<5$ & 1.2 \\
\hline \multirow[t]{4}{*}{$38424-3$} & $2006-703-406-3$ & $<5$ & 2.4 \\
\hline & Average: & $<5$ & 2 \\
\hline & SD: & -- & .7 \\
\hline & RSD: & -- & 35 \\
\hline 38425 & 2006-704-406-1 & 6.2 & 3.9 \\
\hline 38426 & 2006-704-406-2 & 8.7 & 7.2 \\
\hline 38427 & $2006-704-406-3$ & 5.3 & 2.1 \\
\hline 38428 & $2006-705-245-1$ & 16 & 9.6 \\
\hline 38429 & $2006-705-245-2$ & $<5$ & 2.7 \\
\hline 38430 & $2006-705-245-3$ & 18 & 11 \\
\hline 38431 & $2006-705-245-4$ & 9.4 & 5.9 \\
\hline 38432 & $2006-705-245-5$ & 6.2 & 3.7 \\
\hline 38433 & $2006-705-245-6$ & 10 & 11 \\
\hline 38434 & $2006-705-245-7$ & 13 & 7.5 \\
\hline 38435 & $2006-705-245-8$ & 17 & 11 \\
\hline 38436 & $2006-705-245-9$ & 8.1 & 5.2 \\
\hline 38437 & $2006-705-245-10$ & 6.6 & 4.6 \\
\hline 38438 & $2006-705-245-11$ & 10 & 6.7 \\
\hline 38439 & $2006-705-245-12$ & 15 & 9.4 \\
\hline 38440 & 2006-706-245-1 & 5.1 & 3 \\
\hline PB-122106 & & 5.5 & 1.2 \\
\hline \multirow[t]{2}{*}{ PB-010207 } & & $<5$ & .8 \\
\hline & Average: & -- & 1 \\
\hline MB-010107 & Control Bluegill 654C & 8.4 & 5.4 \\
\hline \multirow[t]{2}{*}{ MB-010307 } & Control Bluegill 654C & 9.5 & 5.1 \\
\hline & Average: & 9 & 5.3 \\
\hline MS-OC-010107 & Matrix Spike - OCs & 210 & 270 \\
\hline \multirow[t]{2}{*}{ MS-OC-010307 } & Matrix Spike - OCs & 200 & 250 \\
\hline & Average: & 205 & 260 \\
\hline
\end{tabular}


Table 6. Total chlordanes and summed target chlordane concentrations and percentages in Missouri Department of Conservation 2006 General Contaminant Monitoring fish fillets.-Continued

[USGS, U.S. Geological Survey; ID, identification; MDC, Missouri Department of Conservation; ng/g, nanogram per gram; Average, average of replicate analyses; SD, standard deviation; RSD, percent relative standard deviation; --, no data]

\begin{tabular}{llcc}
\hline \multicolumn{1}{c}{$\begin{array}{c}\text { USGS ID } \\
\text { number }\end{array}$} & \multicolumn{1}{c}{$\begin{array}{c}\text { MDC } \\
\text { field ID }\end{array}$} & $\begin{array}{c}\text { Total technical } \\
\text { chlordanes }^{\mathbf{1}} \\
\text { (ng/g) }\end{array}$ & $\begin{array}{c}\text { Total target } \\
\text { chlordanes }^{2} \\
\text { (ng/g) }\end{array}$ \\
\hline MS-PCB-010107 & Control Bluegill 654C & 25 & 11 \\
MS-PCB-010307 & $\begin{array}{l}\text { Control Bluegill 654C } \\
\text { Average: }\end{array}$ & 6.1 & 3.3 \\
MS-CHLOR-010307 & Matrix Spike - Tech. Chlordane & $\mathbf{1 6}$ & $\mathbf{7 . 2}$ \\
& & 760 & 360 \\
PC-122106 & Saginaw Carp 6806-148 & & \\
PC-010207 & Saginaw Carp 6806-148 & 210 & 75 \\
& Average: & 100 & $\mathbf{7 3}$ \\
\hline
\end{tabular}

${ }^{1}$ Sum of 31 major technical chlordane components including heptachlor, cis/trans-chlordane, cis/trans-nonachlor, but not including heptachlor epoxide, oxychlordane, or methoxychlor metabolites.

${ }^{2}$ Sum of eight targeted components: heptachlor, heptachlor epoxide, oxychlordane, cis/trans-chlordane, cis/transnonachlor, methoxychlor.

Publishing support provided by:

Rolla Publishing Service Center

For more information concerning this publication, contact:

Director, USGS Columbia Environmental Research Center

4200 New Haven Road

Columbia, M0 65201

(573) 875-5399

Or visit the Columbia Environmental Research Center Web site at:

http://www.cerc.usgs.gov 

$\stackrel{\mathbb{D}}{\underline{\underline{D}}}$

$\frac{0}{\text { ब }}$

을

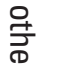

i

变

突.

흘

$\stackrel{ }{\mathscr{0}}$

훙

9 Printed on recycled paper 